\title{
ARCHIWUM PROWINCJI NAJŚWIĘTSZEGO IMIENIA JEZUS ZGROMADZENIA SIÓSTR NAJŚWIĘTSZEJ RODZINY Z NAZARETU W WARSZAWIE ${ }^{1}$
}

Zgromadzenie Sióstr Najświętszej Rodziny z Nazaretu (SS. Nazaretanki) nie ma zbyt długiej historii i pełnego oraz szczegółowego opracowania swych dziejów ${ }^{2}$. Niemniej ma ono chlubne karty historii, o czym wspominał Jan Paweł II w liście do przełożonej generalnej m. M. Teresy Jasionowicz z okazji 125. rocznicy istnienia instytutu ${ }^{3}$. Stanowia je dwie beatyfikacje w Rzymie: 23 kwietnia 1989 roku - założycielki Marii od Pana Jezusa Dobrego Pasterza (Franciszki Siedliskiej) oraz 5 marca 2000 roku - jedenastu Sióstr Nazaretanek Męczennic z Nowo-

* S. Mirosława Górska - mgr filologii polskiej, absolwentka Podyplomowego Studium Archiwistyki UMK w Toruniu, archiwistka prowincjalna Prowincji Najświętszego Imienia Jezus w Warszawie (skrót: ANPW - Archiwum Nazaretanek Prowincji Warszawskiej).

${ }^{1}$ Artykuł powstał na bazie pracy dyplomowej napisanej pod kierunkiem dr hab. Wiesławy Kwiatkowskiej, w Podyplomowym Studium Archiwistyki Uniwersytetu Mikołaja Kopernika w Toruniu w roku 2008.

${ }^{2} \mathrm{Na}$ temat historii zgromadzenia ukazało się kilka pozycji książkowych, traktujących o pewnym odcinku jego historii: Zgromadzenie Najświętszej Rodziny z Nazaretu i jego dzieła 1873 - 1932 , Rzym 1933; F. Tomkowicz, N. Rutkowska, Zgromadzenie SS. Najśw. Rodziny z Nazaretu i jego wktad w dorobek polskiego Millennium, Rzym 1957; M. DeChantal Dylewska, Out of Nazareth, New York 1974 (książka wydana w języku angielskim z okazji 100. lecia istnienia instytutu); H. Markiewicz, B. Stelmaszczuk, Zgromadzenie Sióstr Najświetszej Rodziny z Nazaretu, w: Żeńskie zgromadzenia zakonne w Polsce 1939-1947, t. 7, red. A. Chruszczewski, Lublin 1994, s.121-166; B. Gromada, Rys historyczny zgromadzenia, w: Blask chwały, Rzym 2001, red. T. Górska, N. Wojtatowicz, B. Zamora, s. 13-20, (wydany z okazji 125. lecia zgromadzenia); Ważniejsze daty z historii Zgromadzenia Sióstr Najświętszej Rodziny z Nazaretu, Rzym 1997 (każdy zarząd generalny uzupełnia daty i przekazuje je w formie książeczki prowincjom). Jest to forma utrwalania historii instytutu. Źródło historii stanowią dokumenty takie jak: konstytucje, zwyczajniki, dekrety kapituł, statuty generalne i prowincjalne, okólniki i inne.

${ }^{3}$ Jan Paweł II, List z okazji 125. rocznicy powstania Zgromadzenia Sióstr Nazaretanek, Watykan 2000. 
gródka (rozstrzelanych przez nazistów niemieckich 1 sierpnia 1943 roku), które oddały życie za uwięzionych członków rodzin nowogródzkich i kapłana.

Zgromadzenie Sióstr Najświętszej Rodziny z Nazaretu zostało założone przez Polkę, Franciszkę Siedliską (12 XI 1842-21 XI 1902) w 1875 roku w Rzymie, we Włoszech. Założycielka uważała, że początkiem (duchowym) instytutu jest pierwsza niedziela Adwentu 1883 roku$^{4}$. Ostatecznie placówka przy ul. Machiavellego 18, do której wspólnota się przeniosła w styczniu 1884 roku, stała się kolebką zgromadzenia i była przez osiemdziesiąt lat siedzibą domu generalnego; obecnie ma status domu macierzystego. Od połowy lat 80 . wieku XIX rozpoczął się dynamiczny rozwój fundacji w Europie i Ameryce. W tym samym roku założycielka określiła charyzmat zgromadzenia 5 . Dnia 7 stycznia 1884 ks. Antoni Lechert został zatwierdzony przez władze kościelne jako spowiednik i asystent kościelny zgromadzenia i zajął się prawnym uporządkowaniem spraw we wspólnocie. W dniu 1. maja 1884 miała miejsce właściwa profesja zakonna Franciszki Siedliskiej i jej pierwszych towarzyszek. W tym samym roku, 5 grudnia, odbyły się pierwsze wybory na przełożoną generalną. Została nią założycielka. Pod przewodnictwem ks. A. Lecherta obyły się dwie kapituły generalne: w roku 1895 I Kapituła Generalna w Chaville pod Paryżem (ustalono na niej skład rady, model zarządzania instytutem) ${ }^{6}$ i w roku 1899 II Kapituła Generalna wyborcza (Chaville). Ponownie wybrano na przełożoną generalną Franciszkę Siedliską. III Kapituła Generalna odbyła się w Rzymie w 1902 roku pod przewodnictwem o. Jacka Cormier (ostatniego kierownika duchowego założycielki) i miała na celu przejrzenie konstytucji, które już w roku 1894 przedłożyła założycielka do zatwierdzenia Stolicy Apostolskiej? . W chwili śmierci Franciszki Siedliskiej (21.11.1902 r.) ani konstytucje, ani zgromadzenie nie były przez Kościół zatwierdzone. Instytut

${ }^{4}$ M. Winowska, Dzieje duszy Franciszki Siedliskiej, Rzym 1999, s. 265: „odtąd rocznicę założenia obchodzić będą nazaretanki nie według roku kalendarza, ale według roku liturgicznego: w każdą I Niedzielę Adwentu".

${ }^{5}$ Franciszka Siedliska, Dziennik duchowy, t. 1 (1884), Rzym 2001.

${ }^{6}$ Struktura organizacyjna zgromadzenia jest prawie niezmienna od czasów założycielki: kapituła generalna (najwyższa władza ustawodawcza), zarząd generalny składa się z: przełożonej generalnej, asystentki generalnej, sekretarki generalnej, ekonomki generalnej i radnych (liczba określona w konstytucjach); aktualnie jest pięć radnych. Analogiczne w prowincji: kapituła prowincjalna, zarząd prowincjalny, który składa się z przełożonej prowincjalnej, asystentki, sekretarki, ekonomki $i$ dodatkowych radnych. W prowincji warszawskiej obecnie jedna z radnych odpowiada za formacje, druga za sprawy Wschodu. Na szczeblu domu: kapituła lokalna, przełożona lokalna, która posiada radę lokalną. Stanowią ją: asystentka, ekonomka i dodatkowe radne, w zależności od liczby sióstr w danej placówce. Szczegóły określają konstytucje: kompetencje przełożonych na poszczególnych szczeblach, rolę rady ( jej głos doradczy lub decydujący).

${ }^{7}$ Konstytucje Córek Świętej Rodziny z Nazaretu, w języku francuskim, przedłożono Stolicy Apostolskiej 24 VI 1894. (Tekst polski, Rzym 1977). Po dwóch latach Kongregacja wydała „Dekret pochwalny" (1 IX 1896) i czasowe zatwierdzenie zgromadzenia, z poleceniem zmian niektórych punktów Konstytucji. Założycielka starała się dostosować do otrzymanych uwag, ale w międzyczasie Kongregacja wydała Normy (28 VI 1901). To zmusiło założycielkę do opracowania nowej redakcji Konstytucji, czego dokonała pod koniec życia. 
rozwijał się i w chwili jej śmierci liczył ponad 300 sióstr pracujących w 29 domach, w Europie i Ameryce.

W roku 1906 otwarto dom nowicjatu w Albano ${ }^{8}$ (Włochy) i przeniesiono go $\mathrm{z}$ domu generalnego z Rzymu. Ostateczne zatwierdzenie zgromadzenia dnia 30 lipca $1909^{9}$ roku i „Konstytucji Zgromadzenia Sióstr Najświętszej Rodziny z Nazaret $^{10}$ " $\mathrm{w}$ roku 1923 kończy proces kształtowania się instytutu i praw zgromadzenia.

Zgromadzenie Sióstr Najświętszej Rodziny z Nazaretu, od czasów założycielki, miało charakter międzynarodowy, (choć bardziej lub mniej dominowały w nim dwie liczbowo najliczniejsze grupy: Amerykanek i Polek), wykształciło własną organizację i styl zarządzania: kapituły generalne ${ }^{11}$, kapituły prowincjalne ${ }^{12}$, kapituły lokalne ${ }^{13}$; zarządy: generalny ${ }^{14}$ i prowincjalny ${ }^{15}$, przełożone lokalne i rady lokalne ${ }^{16}$. Od początku zgromadzenie nie stanowiło unii autonomicznych domów, lecz wspólnoty podległe wyższej przełożonej i powiązane ze sobą różnorodnymi zależnościami. Wszystkie siostry obowiązują te same konstytucje ${ }^{17}$ i statuty ${ }^{18}$, ponadto każda prowincja ma własne dyrektorium prowincjalne. Najwyższą, kole-

${ }^{8} \mathrm{~W}$ domu nowicjatu znajdowała się drukarnia sióstr nazaretanek. Po przeniesieniu domu generalnego i nowicjatu do nowego domu w Rzymie przy Via Nazareth 400, drukarni w nim już nie uruchomiono.

${ }^{9}$ Dekret potwierdzający Zgromadzenie Sióstr Najświętszej Rodziny z Nazaretu

${ }^{10}$ Konstytucje Zgromadzenia Najświętszej Rodziny z Nazaretu, część 1-4. Ta nowa redakcja Konstytucji z roku 1903 została przedłożona Stolicy Apostolskiej do zatwierdzenia w 1909 roku i otrzymała czasową aprobatę 2 VIII 1909 roku i ostateczne zatwierdzenie 4 VI 1923 roku.

${ }^{11}$ Kapituła generalna, najwyższy organ ustawodawczy zgromadzenia, podejmuje decyzje dotyczące konstytucji i statutów, uchwały wydawane są w postaci dekretów; ocenia życie duchowe i apostolskie całego instytutu.

12 „Kapituła prowincjalna jest zespołem sióstr, które reprezentują wszystkie siostry prowincji. Zwołuje się ją przed kapitułą generalną oraz przed naznaczeniem nowego zarządu prowincjalnego" Konstytucje, 7.28.

${ }^{13}$ „Wspólnota lokalna zbiera się jako kapituła lokalna, aby zgodnie z Dyrektywami dotyczacymi procedury naznaczania na odpowiedzialne stanowiska:

a. wybrać delegatki na kapitułę prowincjalną lub generalną;

b. uczestniczyć w procesie wyboru zarządu prowincjalnego", Konstytucje, 7.10.

${ }^{14}$ Przełożona generalna komunikuje się z prowincjami i siostrami poprzez okólniki i podaje decyzje zarządu generalnego. Zarząd generalny wydaje biuletyn o swojej działalności i przekazuje siostrom w prowincjach wiadomości.

${ }^{15}$ Przełożona prowincjalna komunikuje decyzje zarządu prowincjalnego siostrom poprzez okólniki. Każda prowincja wydaje swój biuletyn informacyjny i przesyła go do wszystkich domów w prowincji i do domów prowincjalnych zgromadzenia.

${ }^{16}$ „Przełożona lokalna powinna mieć asystentkę. We wspólnotach liczących pięć lub mniej sióstr, wszystkie stanowią radę lokalną. W większych wspólnotach przełożona ma radę składającą się z asystentki i co najmniej jednej siostry, Konstytucje, 7.8

${ }^{17}$ Prawo Miłości, Konstytucje Zgromadzenia Sióstr Najświętszej Rodziny z Nazaretu, Rzym 2002.

${ }^{18}$ Prawo Miłości, Statuty Zgromadzenia Sióstr Najświętszej Rodziny z Nazaretu, Rzym 2002. Po Soborze Watykańskim II, w roku 1965 zniesiono w zgromadzeniu podział na dwie kategorie sióstr (dwa chóry), indult z 20 I 1965. 
gialną władzą ustawodawczą na poziomie zgromadzenia jest kapituła generalna. Należą do niej z urzędu zarząd generalny i przełożone prowincjalne, oprócz nich wchodzą delegatki z wyboru, których liczba winna być podwójna w stosunku do członkiń z urzędu. „Statuty” określają liczbę i procedurę wyborczą delegatek ${ }^{19}$. Zadania kapituły generalnej są następujące:

a. zachęcanie sióstr do życia oddanego Bogu przez śluby i do bardziej autentycznego życia Ewangelia;

b. przejrzenie zgromadzeniowych sprawozdań od przełożonej generalnej, sekretarki i ekonomki generalnej;

c. przeprowadzenie oceny działalności Zgromadzenia i podjęcie planowania na przyszłość w związku ze zmieniającymi się potrzebami Kościoła i świata;

d. rozpatrywanie spraw i wniosków oraz zakomunikowanie podjętych decyzji Zgromadzeniu;

e. wprowadzenie poprawek do „Konstytucji” większością dwóch trzecich głosów oraz poprawek w „Statutach” względną większością głosów; występowanie do Stolicy Apostolskiej o zatwierdzenie zmian w „Konstytucjach”;

f. określenie liczby radnych generalnych i wybór zarządu generalnego;

g. wybór przełożonej generalnej większością dwóch trzecich głosów, oddanych w tajnym głosowaniu ${ }^{20}$.

Kapituła prowincjalna, podobnie jak generalna, ma członkinie z urzędu i wyboru $^{21}$. Do jej zadań należy kierowanie procesem wyboru delegatek na kapitułe generalna, koordynowanie i sfinalizowanie prac przygotowawczych prowincji przed kapitułą generalną oraz kierowanie procesem, według którego zostanie naznaczony zarząd prowincjalny ${ }^{22}$. Kapituła lokalna zbiera się, by wybrać delegatki na kapitułę prowincjalną lub generalną oraz by uczestniczyć w procesie wyboru zarządu prowincjalnego ${ }^{23}$. Zgromadzeniem kieruje przełożona generalna, która wraz z radnymi tworzy zarząd generalny. Składa się on z przełożonej generalnej i radnych ${ }^{24}, \mathrm{w}$ tym $\mathrm{z}$ asystentki generalnej, sekretarki i ekonomki, których kompetencje określają konstytucje ${ }^{25}$ i statuty ${ }^{26}$. Radne generalne, oprócz przydzielonych sobie funkcji, mają w sprawach określonych konstytucjami, głos decydujący lub doradczy (zgoda rady lub opinia rady), który wpływa na decyzję przełożonej generalnej ${ }^{27}$. Zakres praw i obowiązków przełożonej generalnej jest szeroki ${ }^{28}$. Dotyczy wielu spraw: m. innymi: zwoływanie kapituły i jej przewodniczenie, dbałość o formację w zgromadzeniu, wizytowanie zgromadzenia przynajmniej raz w cią-

\footnotetext{
${ }^{19}$ Statuty, Dyrektywy i procedury, \# 4 .

${ }^{20}$ Konstytucje, 7.49

${ }^{21}$ Konstytucje, 7 28, 7.29

${ }^{22}$ Konstytucje, 7.30 i 7.31

${ }^{23}$ Konstytucje, 7.10

${ }^{24}$ Konstytucje, 7.42. Liczbę radnych określa każdorazowo kapituła. Obecnie jest pięć rad-

${ }^{25}$ Konstytucje, 7.42

${ }^{26}$ Statuty, 7.42.3 i 7.42 .4

${ }^{27}$ Konstytucje, 7.37

${ }^{28}$ Konstytucje, 7.36
} nych. 
gu kadencji, wyznaczanie delegatki na dany kraj, o ile zachodzi potrzeba, przesyłanie w oznaczonym czasie do Stolicy Apostolskiej sprawozdania o aktualnej sytuacji zgromadzenia.

Na poziomie prowincji, zarządza prowincją zarząd prowincjalny, i podobnie jak zarząd generalny, składa się z przełożonej prowincjalnej i radnych, w tym asystentki prowincjalnej, sekretarki ${ }^{29}$ i ekonomki ${ }^{30}$, oraz innych radnych, których kompetencje są analogiczne do urzędu na poziomie generalnym. Przełożona prowincjalna ma zakres praw i obowiązków, za który odpowiada sama ${ }^{31}$, inne, które może podejmować za zgodą rady ${ }^{32}$ oraz takie, na które, po uzyskaniu zgody rady, musi mieć zgodę przełożonej generalnej i jej rady ${ }^{33}$. Na poziomie lokalnym wspólnotą kieruje przełożona lokalna i ona podejmuje decyzje określone konstytucja$\mathrm{mi}^{34}$. Rada ma tylko głos doradczy. Posługa władzy w zgromadzeniu jest prosta, taka sama na każdym poziomie i obejmuje: życie duchowe, życie wspólnotowe, apostolstwo, formację i zarządzanie; zróżnicowanie dotyczy zakresu kompetencji przełożonej i roli rady. Konferencje generalne, za kadencji ostatniej przełożonej generalnej ${ }^{35}$, zostały zastapione spotkaniami Komisji planowania, w skład której wchodzi zarząd generalny i przełożone prowincjalne. Odbywają się one co roku w innym kraju, gdzie zgromadzenie posiada domy. Na poziomie prowincji maja miejsce zebrania prowincjalne, oprócz Polski, gdzie z powodu zbyt dużej liczby sióstr są one niemożliwe. Zastępuje je komunikacja poprzez przełożone lokalne, które mają kilka razy w roku spotkania z zarządem prowincjalnym i przekazują siostrom informacje z zebrań. Jedność i różnorodność, centralizacja, ale i podział kompetencji różny na każdym poziomie władzy czynią ze zgromadzenia wspólnotę, w którym mogą odnaleźć miejsce wszystkie narodowości i kultury.

Historia Zgromadzenia Sióstr Najświętszej Rodziny z Nazaretu (nazaretanek) w Polsce sięga czasów założycielki, Franciszki Siedliskiej. Pierwszy dom poza Italia powstał w 1881 roku Krakowie. Następnie powstają: dom we Lwowie (1892), oraz dwa domy w Wadowicach: sierociniec (1896) i szpital (1897). Na terenie zaboru rosyjskiego zgromadzenie rozwijało się tajnie. Powstaje dom w Częstochowie (1902). Początki rozwoju zgromadzenia w Polsce w latach 18811925 (najpierw na terenie Galicji), do czasu kanonicznej erekcji Prowincji Najświętszego Imienia Jezus z siedzibą w Warszawie (1925), oraz próby tworzenia struktur administracyjnych w kraju omawia S. M. Danuta Kozieł ${ }^{36}$

Rok 1918 przyniósł Polsce niepodległość i szybki rozwój działalności zgromadzenia na polu edukacyjnym. Niektóre placówki powstałe w czasie niewoli kontynuują działalność, oraz powstają nowe. We Lwowie - szkoła działała w la-

\footnotetext{
${ }^{29}$ Statuty, 7.23.3

${ }^{30}$ Statuty, 7.23.4

${ }^{31}$ Konstytucje, 7.17

${ }^{32}$ Konstytucje, 7.18

${ }^{33}$ Konstytucje, 7. 19

${ }^{34}$ Konstytucje, 7.7

${ }^{35}$ Janice Fulmer - przełożona generalna od 2001 roku.

${ }^{36}$ D. Kozieł, Poczqtki Nazaretanek na ziemiach polskich, Kraków 2001. Autorka wysunęła hipotezę o istnieniu w latach 1895-1925 Prowincji Galicyjskiej.
} 
tach 1893-1939, w Wilnie (1906) w latach 1906 -1940, Częstochowie (1907 - powstaje drugi dom) - szkoła istniała w latach 1907-1961. W Grodnie (1908) - siostry prowadziły żeńskie gimnazjum z klasami wstępnymi w latach 1915-1921; od 1921 do 1939 szkołę powszechną. W Stryju (1913) - siostry prowadziły żeńskie gimnazjum w latach 1914-1927. Od 1935 do 1939 szkołę powszechną.

Po odzyskaniu niepodległości przez Polskę, powstająnowe domy zakonne i apostolaty. Założono domy i placówki apostolskie: w Warszawie (1918) - szkołę powszechną i średnią (1919), w Kaliszu (1918) - szkołę powszechna i średnią (1918), w Rabce (1919) - szkołę powszechną i średnią (1921-1940), w Nowogródku (1929) - szkołę powszechną w latach 1930-1939, w Ostrzeszowie (1936) - szkołę średnią w latach 1934-1939, w Wadowicach - w latach 1938-1940 szkołę krawiecka, w Kielcach (1939) - planowana na rok 1939 powszechna i średnia szkoła. W roku szkolnym 1938/1939 siostry nazaretanki prowadziły 7 gimnazjów i liceów, 1 gimnazjum krawieckie, 9 szkół powszechnych, 12 internatów i 7 przedszkoli. Bezpośrednio pod opieką sióstr znajdowało się 2.680 uczennic, z czego 568 pozostawało w internatach znajdujących się przy każdej szkole. Do najbardziej licznych należały szkoły w Wilnie, Lwowie i Kaliszu. Wobec szybkiego rozwoju zgromadzenia, w okresie po odzyskaniu niepodległości, powstała konieczność zorganizowania domów w prowincję. W dniu 18 marca 1925 roku została kanonicznie erygowana Prowincja Najświętszego Imienia Jezus. Warszawa została naznaczona jako miejsce zarządu prowincjalnego, a s. M. Bożena Staczyńska powołana na pierwszą przełożoną prowincjalną ${ }^{37}$. Dekretem Świętej Kongregacji dla Spraw Zakonnych z dnia 30 czerwca 1931 roku, podzielono istniejące placówki między dwie prowincje. Linią podziału było odniesienie do 51 stopnia szerokości geograficznej północnej. Domy na północy miały należeć do Prowincji Najświętszego Imienia Jezus, z prowincjalatem w Warszawie, na południu do Prowincji Imienia Maryi ${ }^{38}$, z domem prowincjalnym w Krakowie. Pierwszą naznaczoną przełożoną prowincjalną prowincji Imienia Maryi była s. M. Anna Łyszczyńska ${ }^{39}$. Podział na prowincje nie oznaczał izolacji. Nadal był wspólny nowicjat $\mathrm{w}$ Albano ${ }^{40}$ i Grodnie ${ }^{41}$, istniała między prowincjami wymiana sióstr i wiele wspólnych zachowanych do dzisiaj spotkań ${ }^{42}$.

Okres II wojny światowej i okupacji stanowił nowy rozdział w dziejach Prowincji Najświętszego Imienia Jezus. W czasie jej trwania umarła przełożona generalna m. Laureta Lubowidzka $(\uparrow 15.06 .1942)$. Zastępowała ją wikaria generalna m. Klara Netkowska. Przełożoną prowincjalną w Prowincji Najświętszego Imie-

${ }^{37}$ DeChantal Dylewska, Out of Nazareth, s. 168 - 169.

${ }^{38}$ Kozieł, Poczatki Nazaretanek, s. $69 \mathrm{nn}$.

${ }^{39}$ DeChantal Dylewska, Out of Nazareth, s.176.

${ }^{40}$ Nowicjat w Albano (1906) miały siostry chórowe. Podział na dwa chóry odzwierciedlał ówczesne stosunki społeczne, a przede wszystkim przygotowanie do pracy (pod uwagę brano wykształcenie).

${ }^{41}$ Nowicjat w Grodnie miały siostry konwerskie; z czasem, jeszcze przed Soborem Watykańskim II, podział ten się zacierał.

${ }^{42}$ Rekolekcje sióstr przełożonych w Polsce odbywają się na zmianę, w jednej lub drugiej prowincji. 
nia Jezus była w tym czasie s. M. Anna Łyszczyńska (1938-1948). Ze względu na wojnę nie można było zwołać Kapituły Generalnej Wyborczej. Grupa 28. sióstr (przybyłych z Grodna i Równego) została wywieziona z Wilna na Syberię i przeszła męczeński szlak głodu, więzienia i ciężkiej przymusowej pracy ${ }^{43}$. Po wyjściu z Rosji Sowieckiej grupa sióstr przeszła przez Persję, Afrykę ${ }^{44}$, Anglię opiekując się grupa polskich sierot. Część sióstr pozostała w Anglii i w Pittsford ${ }^{45}$ (19471984) założyła szkołę dla dzieci polskich emigrantów. Niemcy wywieźli w roku 1942 z domu w Kaliszu 27 sióstr i umieścili je w obozie w Bojanowie ${ }^{46}$.

W 1939 roku nazaretanki obu prowincji posiadały 21 domów, z czego Prowincja Warszawska Najświętszego Imienia Jezus miała 10 placówek: Warszawa, Grodno, Wilno, Nowogródek, Łuków, Ostrzeszów (dwa domy), Kalisz, Poznań, Równe ${ }^{47}$. Były to domy własnościowe, liczebnie duże, przy których siostry prowadziły własne apostolaty: szkoły i internaty dla dzieci i młodzieży.

Sytuacja po zakończeniu II wojny światowej okazała się równie trudna jak podczas jej trwania. Po wojnie nastapiła utrata domów na Wschód od linii Curzona (Lwów, Wilno, Grodno, Nowogródek, Równe). Nastapiły: zmiana systemu politycznego, likwidacja placówek oświatowych ${ }^{48}$, prześladowanianie ${ }^{49}$ i konieczność zmiany apostolatu ${ }^{50}$. Liczba domów w prowincji warszawskiej zmniejszyła się do sześciu: Warszawa, Łuków, Żdżary (nowa placówka), Kalisz, Ostrzeszów (2 domy).

W 1989 roku doszło do beatyfikacji założycielki zgromadzenia, Marii od Pana Jezusa Dobrego Pasterza (23 kwietnia), w której siostry z Polski brały liczny udział na czele z przełożoną prowincjalną, s.M. Mariettą Marciniak (1986-1992). Była to pierwsza swobodna możliwość wyjazdu za granicę. Jest to dla Prowincji Najświętszego Imienia Jezus data graniczna, kończy bowiem okres izolacji sióstr od reszty zgromadzenia i rozpoczyna jego szybki rozwój. Zaczyna się czas odzyskiwania utraconych placówek i powrót do właściwych apostolatów, odbudowywanie struktur instytutu na Białorusi; nieoficjalnie zgromadzenie rozwijało się w Grodnie ${ }^{51}$ przy kilku starszych siostrach, które zdecydowały się pozostać i były

${ }^{43}$ Hyacenta (Bieńkowska Janina), Dzieje przeżyć w Rosji Sowieckiej Sióstr Najświętszej Rodziny z Nazaretu 1941-1945, cz. 1-3, Warszawa 1946 [mps].

${ }^{44}$ N. Martusewicz, Tułaczki ciag dalszy Persja - Afryka, Warszawa 1984 [mps].

${ }^{45}$ A. Stawicka, Pitsford, Warszawa 2009.

${ }^{46}$ Siostry nazaretanki w niemieckim obozie pracy w Bojarowie, wspomnienia sióstr (maszynopis).

${ }^{47}$ Po placówce w Równym nie zachowały się żadne akta.

${ }^{48}$ Czasy komunizmu przetrwała jedyna placówka oświatowa w Warszawie, ograniczona do czterech klas liceum. W roku 1981, na prośbę rodziców, pozwolono na otwarcie równoległych klas liceum.

${ }^{49} \mathrm{~W}$ czasach stalinowskich były więzione: przełożona prowincjalna, S. M. Beatrix Kirkor i S. M. Izabela Machowska, która opisała swoje doświadczenia p.t. Moje wspomnienia z lat lask i cierpień (1952-1956) [mps].

${ }^{50}$ Siostrom, po zamknięciu szkoły w Kaliszu, dano pracę fizyczną, pranie fartuchów ze sklepów. Pralnię prowadził także dom w Ostrzeszowie.

${ }^{51}$ Dom w Grodnie powstał w 1908 roku. Był to duży pobrygidzki zespół klasztorny wymierającego zakonu. Arcybiskup wileński Edward Ropp zwrócił się do rządu carskiego z prośbą o pozwo- 
zarejestrowane jako zakonnice. W dniu śmierci ostatniej oficjalnie zgłoszonej nazaretanki ${ }^{52}$ przyszła względna wolnośćs ${ }^{53}$, siostry założyły na jej pogrzeb habity, a w 1992 został otwarty w Grodnie nowicjat ${ }^{54}$. W roku 1995 przeniesiono go do Nowogródka. Zaczęły powstawać nowe domy na Białorusi, w Rosji i na Ukrainie i wyjazdy sióstr na Zachód - była i jest nią pomoc personalna placówkom w Stanach Zjednoczonych (głównie w Texasie i Chicago).

Prowincja Najświętszego Imienia Jezus rozwija się bardzo dynamicznie. Obecnie powstające placówki są niewielkie liczbowo, zazwyczaj domy nie są własnością zgromadzenia, powstają przy parafiach i siostry udają się na tereny „misyjne”, gdzie jest potrzeba ewangelizacji. Są to placówki bardziej mobilne, w razie potrzeby szybciej można je zamykać, przenosić w inne miejsca. Oprócz nich są w prowincji domy własnościowe, do których siostry po zakończeniu aktywnego życia apostolskiego mogą powrócić na starość. W prowincji nie ma (jak w Stanach Zjednoczonych) domów dla sióstr wyłączonych z pracy apostolskiej. Siostry mogą przebywać w głównych domach własnościowych: Warszawie, Kaliszu, Ostrzeszowie i Łukowie, razem z innymi siostrami.

Obecnie Prowincja Najświętszego Imienia Jezus z siedzibą w Warszawie posiada w Polsce 27 domów i 1 dom filialny. Są to placówki w: Bydgoszczy, Ciechocinku, w Jastrzębiej Górze (w) ${ }^{55}$ (+ filia w Jastrzębiej Górze $)^{56}$, Kaliszu (1w) (dwa domy), Kolumnie (w), Lesznie, Lublinie (w), Łukowie (1w) (dwa domy), Obornikach Wielkopolskich, Ostrzeszowie (w), Poznaniu (w), Rawie Mazowieckiej, Roszkowej Woli (w), Warszawie (1w) (trzy placówki, dwa domy), Wasilkowie, Włodawie, Wytycznie (w), Zakopanym(1w) (dwa domy), Ząbkach, Żdżarach (w). Na Białorusi ${ }^{57}$ : Budsław (w), Grodno (1 w) (dwa + filia na Litwie (w), Iwieniec (w), Kościeniewicze, Lida (wł. mieszkanie), Mińsk (dwa), Mołodeczno (w), Nowogródek (w). W Kazachstanie 2: Eskibastuz, Karaganda ${ }^{58}$. W Rosji 3: Kalinin-

lenie przyjmowania kandydatek do opieki nad staruszkami i zajęcia się sprawami klasztoru, który w ten sposób został oddany nazaretankom.

${ }^{52}$ Była nią s. M. Janisława (Anna Lubczyk), zm. 1990. Decyzję o pozostaniu w Grodnie podjęły także: s. M. Berchmans (Konstancja Drozdowska), przełożona sióstr, zm. 1970; s. M. Tekla (Helena Targońska), zm. 1956, s. M. Flawia (Monika Zwierzewicz), zm. 1968; s. M. Elżbieta (Weronika Grochowska), zm. 1973. W czasach komunistycznych siostry z klasztoru usunięto, kościół i klasztor upaństwowiono. Siostry mieszkały przy kościele oo. bernardynów.

${ }^{53}$ Był to rok 1990. Wtedy to oddano siostrom klucze od zamkniętego w 1950 roku kościoła zgromadzenia pod wezwaniem Zwiastowania Najśw. Maryi Pannie. W roku 1992 odbyła się jego konsekracja.W roku 1994 zgromadzenie otrzymało na Białorusi osobowość prawną jako związek religijny. Olbrzymi kompleks budynków klasztornych w Grodnie, zrujnowany przez szpital psychiatryczny, przejęła diecezja (2005). Dom zakonny i budynek szkolny w Nowogródku zgromadzenie odzyskało w 1992 roku.

${ }^{54}$ Okres prześladowań Kościoła trwał do 1985 roku, kiedy to Michał Gorbaczow na 27 zjeździe Komunistycznej Partii ogłosił rozpoczęcie w państwie pierestrojki.

${ }^{55} \mathrm{~W}$ - własność zgromadzenia.

56 Planowany na rok 2008 dom nie zaistniał.

${ }^{57}$ Z 10. domów na Białorusi została utworzona 13 września 2008 Prowincja Błogosławionych Męczennic z Nowogródka

${ }^{58}$ Dom w Karagandzie zamknięto w roku 2009 (lipiec). 
grad, Nowotroick, Togliatti. Na Ukrainie 2: Czerwonoarmijsk, Żytomierz (w) ${ }^{59}$. Stan liczebny Prowincji za rok 2006 przedstawia się następująco: liczba profesek czasowych i wieczystych - 401. W tym: profesek wieczystych 345, profesek czasowych -56 , nowicjuszek -15 , postulantek $-13^{60}$.

\section{DZIEJE ARCHIWUM PROWINCJI NAJŚWIĘTSZEGO IMIENIA JE- ZUS ZGROMADZENIA SIÓSTR NAJŚWIĘTSZEJ RODZINY Z NAZA- RETU W WARSZAWIE I JEGO STAN OBECNY}

\section{Kancelaria prowincjalna}

Archiwum jest nierozłącznie związane z kancelarią. Za kancelarię odpowiada sekretarka prowincjalna, której obowiązki określają Statuty ${ }^{61}$. W kancelarii wytwarzane są akta, które później trafiają do archiwum. Organizacją kancelarii zajęła się po raz pierwszy S. Anna Czech, sekretarka i ekonomka w jednej osobie w latach 1972-1980. Po niej, były kolejno: S. M. Teofila Woźniakowska (1980-1986), pełniąca również funkcję ekonomki, S. M. Franciszka Chuda (1986-1992), S. M. Laureata Pałka (1992-1998), S. M. Amata Nowaszewska (1998-2004) i aktualna sekretarka, S. M. Angela Szczawińska (2004). Dwie ostatnie sekretarki posiadają biegła znajomość jęz. angielskiego, co jest niezbędne przy kontaktach z innymi prowincjami zgromadzenia i zarządem generalnym. O urządzeniu kancelarii można mówić od roku 1992, kiedy w domu warszawskim, w wyniku odzyskania własności, zmieniły się warunki lokalowe. Obecna kancelaria jest wyposażona w komputer, skaner, drukarkę, faks, telefon, kopiarkę i telefon komórkowy. Sekretarka posiada łączność elektroniczną ze wszystkimi domami zgromadzenia, co upraszcza i usprawnia pracę. Biuro stanowi tylko miejsce pracy. Kancelaria prowincjalna jest jednoosobowa, stąd wiele procedur jest uproszczonych, nie ma potrzeby „obiegu pisma” $i$ innych koniecznych w wieloosobowym zespole czynności. „Statuty" zgromadzenia wyraźnie określają zadania sekretarki prowincjalnej i brzmią następująco: „Sekretarka prowincjalna sporządza i przechowuje protokóły posiedzeń rady. Obowiązki jej w prowincji są podobne do obowiązków sekretarki generalnej w Zgromadzeniu"62, a szczegółowe wskazówki opracowuje sekretarka generalna ${ }^{63}$. Do głównych obowiązków sekretarki prowincjalnej należą:

1. pisanie protokołow z posiedzeń rady prowincjalnej (raz w miesiącu) i zebrania sióstr przełożonych (kilka razy do roku);

${ }^{59}$ Zgromadzenie Sióstr Najświętszej Rodziny, Dyrektorium adresowe, Warszawa 2007/2008 (maszynopis).

${ }^{60}$ Annual Statistical Report of Holy Name of Jesus Province, December 31, 2006, s.73.

${ }^{61}$ Statuty, \# 23.2

${ }^{62}$ Statuty, \# 7. 23. 2.

${ }^{63}$ R. Bradley, Provincial Secretaty's Manual, Rome 1991; Provincial Secretaty's Manual, Revised February, 2005. 
2. korespondencja z władzami kościelnymi (z diecezjami i parafiami) i świeckimi, elektroniczna i listowa;

3. komunikacja z domami (wszelkie informacje przesyłane drogą e-mailowa) lub listowną;

4. wysyłanie poczty sekretariatu;

5. sporządzanie co roku sprawozdania statystycznego dla zarządu generalnego, dla konsulaty, prowincji, Instytutu Statystki Kościoła Katolickiego (ks. pallotyni);

6. komunikacja międzyzakonna (pisma okolicznościowe i informacyjne);

7. zbieranie z prowincji materiałów i redagowanie periodyku o życiu prowincji „Tęcza”, rozsyłanie go do domów prowincji i domów prowincjalnych na całym świecie (redagowane w niej krótkich tekstów po angielsku);

8. aktualizacja strony internetowej zgromadzenia;

9. uczestniczenie w radach i podejmowanie decyzji odnośnie prowincji;

10. redagowanie i wydawanie co roku „Dyrektorium adresowego zgromadzenia" dla wszystkich domów prowincji i instytucji;

11. przepisywanie, robienie kserokopii, zaopatrywanie biura, konserwacja sprzętu.

Układ dokumentów (registratura wytworzonych akt) jest następujący:"A" charyzmat. Matka Założycielka, Siostry Męczenniczki, Siostra Małgorzata (Banaś), „B”64, „C” (informacje personalne), „D” (domy). W kancelarii nie ma instrukcji kancelaryjnej, jest natomiast dziennik podawczy.

Jako pomocy siostra sekretarka używa:

1. kart personalnych i dokumentacji sióstr żyjących;

2. kartoteki postulantek;

3. księgi nowicjuszek;

4. księgi sióstr profesek chórowych, od 1966 wszystkich sióstr profesek;

5. klucza - alfabetycznego spisu sióstr profesek;

6. księgi głównej - ewidencji sióstr Prowincji Najświętszego Imienia Jezus w Warszawie, cz. II B, od roku 1931;

7. prawa kanonicznego z roku 1984;

8. dokumentów soborowych

9. książki Elio Gambari, Życie zakonne po Soborze Watykańskim II, Kraków 1998;

10. Prawa Miłości. Konstytucji i Statutów Zgromadzenia Sióstr Najświętszej Rodziny z Nazaretu, Rzym 2002;

11. Akt Kapitut Generalnych (od XVII kapituły);

12. dyrektoriów prowincjalnych;

13. wzorów umów i druków;

14. tekstów liturgicznych odnośnie do ślubów pierwszych i wieczystych;

15. teksów liturgicznych odnośnie do świąt bł. Franciszki Siedliskiej i bł. Nazaretanek, Męczennic z Nowogródka;

16. pism Franciszki Siedliskiej;

${ }^{64}$ Patrz załącznik nr 2 
17. elektronicznego systemu ewidencji (Zakon Egid) - danych osobowych dla żeńskich zgromadzeń zakonnych.

Kancelaria i wytwarzane przez nią dokumenty ,zasilają” archiwum prowincji, ale nie są jedynym źródłem bogacenia jego zasobu. Wydaje się, że dotąd nie było między archiwum a kancelarią jednakowego systemu oznaczania akt. Na przykład w kancelaryjnym zespole „B” znajdują się akta o różnorodnej tematyce: korespondencja, apostolstwo, akta kapituły, itp. Aby je uporządkować, trzeba stworzyć przejrzysty system i zastosować go w kancelarii i w archiwum. Tym bardziej, że jawi się perspektywa nie tylko wzajemnej współpracy z kancelaria, ale i poszerzenia archiwum o kolejne pomieszczenie.

\section{Okoliczności powstania archiwum}

Przed wojną nie było w Warszawie, jako odrębnej jednostki, archiwum prowincjalnego. Zbyt krótki był czas istnienia prowincji (1925-1939). $Z$ tego względu dokumentację aktową gromadzono w poszczególnych domach. Były to placówki własnościowe, wyrastały równocześnie z dziełami apostolskimi, im służyły. Poza tym nie były tak liczne jak obecnie. Świadomość wartości i ważności akt istniała $\mathrm{w}$ Zgromadzeniu od początku. $\mathrm{O}$ archiwach i archiwaliach pojawiają się wzmianki w konstytucjach (1890), zwyczajnikach (1929, cz. 2, VII; 1958, cz. 2,VII), statutach $(1969,212 \mathrm{~h})$ i uchwałach $(1955,2,22)$. Wytyczne do prowadzenia archiwum prowincjalnego pochodzą z roku $1985^{65}$. Ostatnie zgromadzeniowe zalecenia zawarte są w Provincial Secretary's Manual z roku 200566. W czasie ostatniej wojny wiele akt zaginęło ${ }^{67}$. Trudna sytuacja zgromadzenia w Polsce w czasach PRL'u, nie pozwalała na wcielanie w życie zaleceń ogólno-zgromadzeniowych odnośnie do prowadzenia archiwum prowincjalnego; co więcej zagrożone było samo istnieniu instytutu. Okres PRL, a szczególnie lata stalinowskie (1950-1955) ze względu na możliwość aresztowań, był okresem niszczenia dokumentów, fotografii ${ }^{68}$, a w obawie rewizji ${ }^{69}$ celowo nie prowadzono dokumentacji.

${ }^{65}$ Wytyczne do prowadzenia archiwum, Siostry Najświętszej Rodziny z Nazaretu , Rzym 1985, $\mathrm{s.1} \mathrm{nn}$. Zawierał tytuły: archiwum (przepisy zgromadzeniowe $\mathrm{z}$ tej dziedziny), zbiory archiwalne, korzystanie $\mathrm{z}$ archiwum, archiwistka, archiwistka generalna, archiwistka prowincjalna, archiwa domów lokalnych, archiwa instytucji, noty uzupełniające, artykuł 143 Dekretów Kapituły Generalnej z 1966 roku: A. dział ogólny, B. Dział materialnego zarządu zgromadzenia, specjalne zbiory sióstr, indeks.

${ }^{66}$ Provincial Secretary's Manual, Rome, revised February, 2005, s. 5-6; 22-27 dotyczą archiwum (nie ma tłumaczenia na jęz. polski).

${ }^{67}$ Kronika domu warszawskiego została odtworzona retrospektywnie przez s. M. Elektę Piątkowską.

${ }^{68}$ Nowicjuszki niszczyły swoje rodzinne fotografie, by nie narażać rodziny na prześladowania - wspomina s. M. Rafaela Wielgut.

${ }^{69}$ Przed aresztowaniem we wrześniu 1952 roku s. M. Beatrix Kirkor, przełożonej prowincjalnej, zniszczono kompromitujące ją dokumenty. W domu prowincjalnym odbywały się spotkania sióstr prowincjalnych z Prymasem Stefanem Wyszyńskim, na których omawiano ówczesną sytuację zakonów. 
Nie było w tym czasie kontaktu z zarządem generalnym w Rzymie. Zgromadzenie nastawione było na przetrwanie i bierny opór. Obowiązek gromadzenia akt spoczywał na sekretarce prowincjalnej w ramach jej pracy w sekretariacie. Przywiezione po zlikwidowanych po wojnie domach (Wilno, Grodno, Nowogródek) akta przechowywano w szafach: w biurze przełożonej prowincjalnej, na korytarzu 2 piętra klauzury ${ }^{70}$, bieżące w sekretariacie ${ }^{71}$. Pierwszą powojenną ekonomką i sekretarką, która założyła segregatory w kancelarii i uporządkowała akta, była s. M. Anna Czech. Pełniła tę funkcję w latach 1972-1980 Pod kierunkiem prof. J. Kłoczowskiego została podjęta inicjatywa opracowania tematu „Żeńskie wspólnoty zakonne w Polsce w okresie 1939-1947'72. Z ramienia prowincji warszawskiej została wydelegowana s. M. Deodata (Helena Markiewicz), która zaczęła jeździć po domach, robić wywiady z siostrami, gromadzić dokumenty z różnych placówek i opracowywać je. Zaowocowało to artykułem we wspomnianej już pracy zbiorowej na temat zgromadzeń żeńskich ${ }^{73}$. Dokumenty zgromadzone w szafach na korytarzu 2 piętra klauzury i te zebrane przez s. M. Deodatę stanowily początek archiwum prowincjalnego.

Pierwszą archiwistka, powołaną do pracy w ,archiwum” została s. M. Noela (Janina Martusewicz (1905-2003) ${ }^{74}$. W archiwum pracowała w latach 1982-2001. Sama zainteresowana tak opisuje nominacje na archiwistkę: „Gdy w roku 1982 s. Kazimiera Kuc, ówczesna [przełożona] prowincjalna zaproponowała mi pracę $\mathrm{w}$ archiwum prowincjalnym, byłam zbulwersowana (...). Owszem, dostałam pouczenie czysto teoretyczne, gdyż samo archiwum krakowskie mieściło się na ul. Warszawskiej w Krakowie, a siostra archiwistka ${ }^{75}$ mieszkała ze swymi katalogami w Komańczy... Zdobytych informacji wprowadzić w życie nie mogłam dla bardzo prostej przyczyny - tj. braku warunków czysto materialnych. Archiwum warszawskie mieściło się w zamkniętych szafach umieszczonych na przechodnich korytarzach 2 piętra klauzury. Zaczęłam zapoznawać się z zawartością szaf, nie znalazłam w nich żadnego katalogu. Mogłam pracować od dzwonka do

${ }^{70}$ Szafy były zamknięte na klucz, który miała przełożona prowincjalna lub sekretarka. W związku z upaństwowieniem i zabraniem zgromadzeniu dużej części budynku, w klasztorze było ciasno i nie było miejsca na archiwum. Na korytarzu trzeciego piętra klauzury stała szafa z dokumentami szkolnymi (archiwum szkolne).

${ }^{71}$ Sekretariat był równocześnie pokojem mieszkalnym danej siostry, która posiadała jako pomoc maszynę do pisania.

${ }^{72}$ Instytut Geografii Historycznej Kościoła w Polsce Katolickiego Uniwersytetu Lubelskiego, Instrukcja dla opracowania materiatów: Żeńskie wspólnoty zakonne w Polsce w okresie 1939-1947, Lublin 1975.

${ }^{73}$ S. M. Deodata (Helena Markiewicz, 1904-1986). Od 1972 opracowuje historię domów Prowincji Najświętszego Imienia Jezus. Współautorka: Zgromadzenie Sióstr Najświętszej Rodziny z Nazaretu, w: Żeńskie wspólnoty zakonne w Polsce w okresie 1939-1947, Lublin 1994.

${ }^{74}$ Siostra nie posiadała przygotowania archiwstycznego; była osoba inteligentną, o bogatym doświadczeniu życiowym. Charakteryzowała ją miłość do przeszłości i pasja ratowania jej od zapomnienia.

${ }^{75}$ Archiwistką Archiwum Nazaretanek Prowincji Krakowskiej była w tym czasie s. M. Lucillina (Bogumiła Stelmaszczuk). 
dzwonka ${ }^{76}$, po czym wszystko trzeba było chować do szafy. Inwentaryzacja odpadała. Powstawały projekty przeniesienia szaf na bardziej odpowiednie miejsce ale skończyło się na projektach (...) Przeglądając teczkę po teczce znalazłam bardzo ciekawe wspomnienia - często nie podpisane, ale (napisane) znanym mi charakterem pisma - zaczęło mnie [to] wciaggać, interesować, rodziła się pasja ratowania korzeni odchodzącej przeszłości. Znalazłam swoje miejsce, swoje zadanie" 77 . Dalej siostra wspomina: „Po zapoznaniu się z jego zawartością [archiwum] zrozumiałam jedyne stojące przede mną zadanie - możliwe do wykonania: jakoś scalić te rozrzucone po teczkach dokumenty, strzępy wspomnień, zapisy historyczne nowych fundacji - stworzyć uszeregowany rys historyczny domów zgromadzenia w Polsce, poczynając od założonego przez Założycielkę domu w Krakowie, wykorzystując własne doświadczenie, znajomość osób i spraw, w których często brałam udział. Zdawałam sobie sprawę z tego, że należę do nielicznych już żyjących świadków minionej epoki. To zobowiązuje"78. Tak więc sprawa uporządkowania akt przesunęła się na dalszy plan, gdyż siostra archiwistka zajęła się pisaniem na temat wybranych zagadnień $\mathrm{z}$ historii zgromadzenia ${ }^{79}$.

W 1990 roku zgromadzenie odzyskało wszystkie pomieszczenia w swoim budynku, zajmowane dotychczas przez władze państwowe. W roku 1992, po remontach i wykonaniu szaf, nastapiło przeniesienie archiwum z korytarza do pokoju na I piętrze, do tzw. prowincjalatu. Pokój ma wymiary 6 metrów długości i 3.20 szerokości. Zawiera siedem jednorodnych szaf trzyczęściowych, dwudrzwiowych (jedna wnękowa z nadstawka), o szerokości $144 \mathrm{~cm}$ na wysokość $212 \mathrm{~cm}$ i głębokości $34 \mathrm{~cm}$. Wewnątrz szafy jest sześć półek. Nadstawka szafy wnękowej ma 92 cm wysokości, pozostałe wymiary są takie same. Oprócz tego w pokoju znajduje się na ścianie północnej szafa przeszklona, dwudrzwiowa (o wysokości $212 \mathrm{~cm}$,

${ }^{76} \mathrm{~W}$ klasztorze poszczególne zajęcia oznajmia się wspólnocie dzwonkiem (modlitwy, posiłki, rekreacje, itp.).

${ }^{77}$ N. Martusewicz, Przemyślenia na temat pracy w archiwum, Warszawa 1996, s. 1.

${ }_{78}^{7}$ Tamże, s. 3

${ }^{79}$ 1. Martusewicz, Tułaczki ciag dalszy Persja-Afryka, ANPW;

2. Ankietę Wydziału Spraw Zakonnych odnośnie do sytuacji zgromadzenia w latach 1945-1989 ;

3. O założycielce: N. Martusewicz, Czcigodna Stużebnica Boża Maria od Pana Jezusa Dobrego Pasterza, Franciszka Siedliska, Warszawa 1987;

4. Pomagała przy thumaczeniu książki A. Ricciardi, Francesca Siedliska, Roma 1970; wyd. polskie A. Ricciardi, Franciszka Siedliska, Rzym 1987, tł. s. M. Immolata Krajeńska, W. Minkiewicz.

5. Pomagała przy pisaniu książek wyszukując i dostarczając potrzebne dokumenty:

a) Z. Martusewicz, Obcujac ze świętymi, Warszawa 1988.

b) przy monografii o szkole wileńskiej, N. Martusewicz, Powstanie szkoły Nazaretanek $w$ Wilnie. Dom Zgromadzenia Sióstr Najświętszej Rodziny z Nazaretu, w: J. Hoppen-Zawadzka, J. Cywińska, Dzieje powstania i działalności szkoły Sióstr Najświętszej Rodziny z Nazaretu $w$ Wilnie w latach 1906 - 1940, Bydgoszcz 1996, s. 19-26;

6. Opracowała historię prowincji, N. Martusewicz, Historia prowincji warszawskiej, t. 1-5, Warszawa 1993 [mps]. 
szerokości $124 \mathrm{~cm}$ i głębokości $34 \mathrm{~cm}$ ). Zawartość szaf w metrach bieżących wynosi 67. 28. Pojemność w metrach kwadratowych zawiera się w cyfrze 8,61m. Rozmieszczenie szaf: na ścianie zachodniej pokoju znajdują się trzy szafy. Przy oknie, na ścianie południowej, jedna; dwie szafy, złączone plecami, są równoległe do szafy przy oknie. Między tymi szafami jest szafa w ścianie z muzealiami. Na tej samej ścianie co szafa w ścianie, znajduje się, za zlewem, szafa wnękowa (z nadstawką). Nad sześcioma jednakowymi szafami znajdują się pudła (trzy na każdej szafie, razem osiemnaście), w których przechowywane są albumy z większych domów. Nad szafą przeszkloną, są dwa wysokie pudła, które zawierają się różne plany. Akta w szafach na półkach są ułożone bibliotecznie i poziomo. W pokoju znajduje się biurko, dwa krzesła, a od roku 2001 komputer na stoliku, lampa biurowa, przy nim krzesło obrotowe, drukarka z faksem i skanerem, oraz telefon i dwie drabiny (wysoka metalowa za szafa). Siostrze Noeli od grudnia 1992 roku do 1994 pomagała przy przenoszeniu i segregowaniu dokumentów s. M. Gabriela Ciołek, która także przepisywała księgę główną ${ }^{80}$. Pierwsze porządkowanie polegało na przeniesieniu do archiwum (powyżej opisanego pokoju) akt z szaf drugiego piętra, posegregowaniu ich, włożeniu do teczek, podpisaniu i umieszczeniu w szafach. Akta rozdzielano wg tzw. zespołów ${ }^{81}$ archiwalnych, umownie przyjętych $^{82}$. Przy tym porządkowaniu zasobu nie zrobiono żadnego spisu zawartości poszczególnych szaf, nie oznaczono ich kategoriami, które służyły ich rozdzieleniu. s. M. Noela miała fenomenalną pamięć i wiedziała co w poszczególnej szafie i na której półce się znajduje. Zwykła mawiać, że ma komputer w głowie. Wydaje się, że była bardziej zainteresowana popularyzowaniem treści archiwaliów i ich poznawaniem, niż porządkowaniem archiwum. Sama tak pisze: „Po co to wszystko pisałam? (...) Chciałam sobie odpowiedzieć i innych o to zapytać, czy dobrze zrobiłam «ratując od zapomnienia [wydarzenia]» jako naoczny świadek przeszłości czy raczej trzeba było sporządzić katalogi. To pierwsze wydawało mi się ważniejsze i nie żałuję, że takiego dokonałam wyboru, mam wewnętrzną satysfakcję, że to się kiedyś przyda. Niemniej lękam się o te nie spisane zasoby archiwalne; ile czasu wymagało nauczenie się wszystkiego na pamięć"83. Siostrze Noeli w ostatnich latach pomagała dorywczo s. M. Józefa Kobiela. Odchodząc z pracy w archiwum s. M. Noela miała 96 lat.

W roku 2001 następuje zmiana na stanowisku archiwistki prowincjalnej. Archiwum objęła s. M. Teresa Górska (Mirosława Górska), polonistka, również jak poprzednia siostra bez przygotowania archiwistycznego. Rozpoczęcie pracy poprzedziła konsultacja z s. Krystyną Dembowską, historykiem, która zasugerowała

${ }^{80}$ Księga główna zawiera spis wszystkich sióstr od początku istnienia zgromadzenia. Spis sporządzano w oparciu o kopię tej księgi z Archiwum Nazaretanek Prowincji Krakowskiej. Oryginalna księga najprawdopodobniej zaginęła.

${ }^{81}$ Wydzielone części zostały błędnie nazwane zespołami.

${ }^{82} \mathrm{~A}$ - podstawy prawne i organizacyjne, $\mathrm{B}$ - zarząd zgromadzenia, $\mathrm{C}$ - personalia, D - domy, E - finanse, F - korespondencja i dokumenty władz kościelnych, $\mathrm{G}$ - korespondencja i dokumenty władz i instytucji cywilnych, $\mathrm{H}$ - materiały do historii zgromadzenia, I - publikacje. Dorobek piśmienniczy zgromadzenia. Materiały kancelaryjne.

${ }^{83}$ Martusewicz, Przemyślenia na temat pracy $w$ archiwum, s. 5. 
zwiedzenie kilku archiwów zakonnych, o uporządkowanych zasobach. S. M. Teresa odwiedziła Archiwum Sióstr Służebniczek Śląskich we Wrocławiu i postanowiła zacząć pracę od porządkowania. W związku z brakiem spisu akt, aby rozeznać się w całości, zaczęła od przygotowania warsztatu pracy. Był to zakup komputera, drukarki z faksem i skanerem, zamówienie u introligatora segregatorów na akta (robionych na wymiar z tektury i płótna, by wykorzystać aktualne szafy), pudeł na albumy (na wymiar) w związku z planowanym umieszczeniem ich na szafach (za mało miejsca w pokoju). Następnie zakupiono dużą liczbę teczek papierowych i innych, potrzebnych do tego typu pracy pomocy. W szafach wywiercone zostały otwory u dołu, w środku i u góry, by zapewnić wietrzenie archiwaliów. Na górze pudła zostały ustawione na dwóch listewkach, by wyloty wywierconych otworów nie były zamknięte. Do szaf dokupiono klucze i je dopasowano, by się zamykały. Wszystkie akta były wyjęte, szafy czyszczone i konserwowane. W roku 2006 archiwum zostało pomalowane. W roku 2007, w związku z wymianą w domu kaloryferów (obecny ma termostat) i remontem (na piętrze II, III i IV ) w czerwcu, lipcu i sierpniu archiwum było nieczynne. $Z$ dwóch szaf dokumenty wyjęto (szafa wnękowa i przeszklona) i przeniesiono do pomieszczenia zastępczego, gdyż przeprowadzany pion kanalizacyjny przechodził także przez archiwum.

Porządkowanie zaczęło się od rozplanowania i oznaczenia miejsca rozmieszczenia wydzielonych części archiwaliów, błędnie nazwanych zespołami (wywieszki na szafach). Następnie wyjmowano partiami akta. Następowała wymianie teczek plastikowych i zużytych na nowe papierowe, oznaczano je i zapisywano w komputerze, choć nie był to opis fachowy. Schemat podziału na wydzielone części podany przez poprzednią siostrę archiwistkę ${ }^{84}$ wydawał się logiczny, dlatego go przyjęto. Przy okazji następowało brakowanie ${ }^{85}$. Oprócz tego w obrębie niektórych tzw. zespołów, np. D ( domy), stworzono podzespoły (1-10), by w ten sam sposób rozmieścić akta we wszystkich domach. Czasem był to układ chronologiczny (zespół I), innym razem ważnością akt. I tak w szafie od strony zachodniej (najbliżej okna, gdzie stoją obok siebie trzy szafy) zastał umieszczony zespół A ( w dalszej kolejności szaf, zespół D).

W zespole A: Podstawy prawne i organizacyjne zgromadzenia - są skatalogowane wg chronologii: I. Konstytucje, II. Zwyczajniki, dyrektoria i statuty, III. Dekrety kapituły generalnej, IV. Ceremoniały, V. Modlitewniki zgromadzenia, VI. Podręczniki nazaretańskiej formacji, VII. Dyrektoria prowincjalne, VIII. Zgromadzeniowe ksiazżki adresowe z podziałem na prowincje i domy.

Zespół B: zarząd zgromadzenia - nie został skatalogowany (jest to szafa stojąca z drugą plecami do siebie, zwrócona na północ, góra). Znajdują się w jej górnej części dokumenty $\mathrm{w}$ segregatorach, teczkach związane $\mathrm{z}$ administracja prowincji i nie tylko, np. protokoły rad prowincjalnych, okólniki przełożonej prowincjalne, ale i generalnej, statystyki zgromadzenia, programy formacyjne poprzednich zarządów ).

\footnotetext{
${ }^{84}$ S. M. Noela nazwała błędnie wydzielone działy zespołami.

${ }^{85}$ Brakowaniu poddano kopie, których było b. dużo, dokumentację kościelną (różne listy okólne drukowane), która obecnie są w wydaniu książkowym, itp.
} 
Zespół C: personalia - znajduje się na dole w szafie zespołu B i wnękowej (segment od dołu) oraz na dwóch półkach szafy przeszklonej. Spisano go i wyróżniono w nim: I. aspirantki, II. Postulantki, III. Nowicjuszki, IV. Juniorystki, V. Skrutynia, opinie i decyzje zarządu prowincjalnego, VI. Formacja po ślubach wieczystych, VII. Dokształcanie religijne sióstr, VIII. Jubileusze sióstr, IX. Siostry przebywające na eksklaustracji, X. Siostry ślubów wieczystych, które opuściły zgromadzenie, XI. Karty personalne sióstr zmarłych, XII. Księga zmarłych sióstr, XIII. Wspomnienia pośmiertne o siostrach w jęz. polskim, XIV. Wspomnienia pośmiertne o siostrach w jęz. angielskim, XV. Księgi ewidencyjne podręczne (I, II), XVI. Księgi posagów sióstr, XVII. Testamenty, posagi, różne stare dokumenty, XVIII. Meldunki, XIX. Emerytury, XX. Księga główna, XXI. Teczki personalne sióstr zmarłych, XXII. Teczki Przełożonych generalnych, XXIII. Teczki Przełożonych prowincjalnych, XXIV. Teczki z dorobkiem sióstr, XXV. Materiały do beatyfikacji S. M. Małgorzaty Banaś.

Zespół D: domy prowincji i ich działalność - zajmują (poza zespołami A i F - nieskatalogowanymi, na najniższej półce) szafy położone na zachodniej ścianie archiwum (trzy szafy obok siebie). Domy na półkach ustawione są w dużych oznaczonych segregatorach (zielone boksy) chronologicznie. Podana jest pełna nazwa domu, rok jego założenia, adres. W obrębie danego domu istnieje podział na: 1 . dokument erekcji domu, 2. wykaz przełożonych wg chronologii, 3. umowy o pracę, 4. historia domu, 5. plany domu (przy domach własnościowych), 6. kroniki, 7. sprawozdania roczne, 8 . różne materiały dotyczące historii domu, 9. przedszkole / inny rodzaj apostolstwa, 10. szkoły. I tak mamy: I. Warszawa, II. Grodno, III. Kalisz, IV. Nowogródek. V. Ostrzeszów, VI. Łuków 1, VII. Żdżary, VIII. Ząbki, IX. Rawa Mazowiecka, X. Łuków 2, XI. Lublin, XII. Wytyczno, XIII. Kolumna, XIV Bydgoszcz, XV. Oborniki, XVI. Zakopane 1, XVII. Leszno, XVIII. Jastrzębia Góra, XX. Czerwonoarmijsk, XXI. Lida, XXIII. Kaliningrad, XXIV. Druskienniki (filia Grodna), XXV. Ciechocinek, XXVI. Mińsk, XXVII. Roszkowa Wola, XXVIII. Konin, XXIX. Warszawa 2, XXX. Poznań, XXXII. Wasilków, XXXIII. Iwieniec, XXXIV. Zakopane 2, XXXV. Włodawa, XXXVI. Mołodeczno, XXXVII. Nowotroick, XXXVIII. Kalisz 2, XXXIX. Grodno 2, LXI. Warszawa 3, LXII. Żytomierz (Czudnów. Filia domu w Żytomierzu), LXIII. Budsław, LXIV. Kościeniewicze, LXV. Mińsk 2, Togliati (istnieje od 14.11. 2006 roku i podlega zarządowi prowincjalnemu, Ekibastuz, Karaganda, Jastrzębia Góra 2.

D - Domy zlikwidowane: LXI. Warszawa (dom przeniesiony do innej parafii w Warszawie, pod ta samą nazwa), XXII. Szczuczyn, XXXI. Madryt, LX. Suwałki, XIX Gniezno, Nowojelnia (od 2004 roku jako filia Domu w Nowogródku).

Zespół E: finanse.

Zespół $\mathrm{F}$ - korespondencja i dokumenty władz kościelnych.

Zespół $\mathrm{G}$ - korespondencja i dokumenty władz i instytucji cywilnych.

Zespół $\mathrm{H}$ - materiały do historii zgromadzenia - nie zostały skatalogowane.

Zespół I podzielono na części: I. Publikacje własne zgromadzenia, wydania książkowe, II. Publikacje własne zgromadzenia, artykuły, III. Publikacje o zgromadzeniu, wydania książkowe, IV. Publikacje o zgromadzeniu, artykuły, V. Prace dyplomowe i magisterskie sióstr, VI. Maszynopisy sióstr, VII. Maszynopisy osób 
spoza zgromadzenia, VIII. Kasety video o zgromadzeniu i pracy sióstr, IX. Taśmy magnetofonowe, $\mathrm{CD}$ (dorobek sióstr) i inne, X. Albumy (numery pudel i informacja z jakich domów), XI. Fotografie - klisze, slajdy, XII. Pieśni (z nutami i bez), XIII. CD, XIV. Zabytki i pamiątki. Opracowano część V, która znajduje się w szafie wnękowej w części środkowej i nadstawce. Skatalogowano 200 prac dyplomowych i magisterskich w porządku chronologicznym, wg autorów. Sporządzono katalog prac poświeconych założycielce, duchowości zgromadzenia i jego historii. Opracowano część VIII. Kasety video o zgromadzeniu i pracy sióstr (56 pozycji skatalogowanych, znajdują się w nadstawce szafy wnękowej). Opracowano część IX. Taśmy magnetofonowe, CD (dorobek sióstr) i inne. (34 pozycje, znajdują się w nadstawce szafy wnękowej). Opracowano część X. Albumy (18). Opracowano część XI. Fotografie (klisze, slajdy (9: pudełka, teczki, koperty (znajdują się w nadstawce szafy wnękowej). Opracowano część XIII. CD (3 pozycje). W szafie przeszklonej, na najwyższej półce, znajdują się w słojach, zamknięte i opieczętowane, podpisane, relikwie, drugiej klasy; są to pozostałości z wnętrza trumien bł. sióstr, Męczennic z Nowogródka, wydobyte podczas drugiej ekshumacji. Przed słojami stoją ich fotografie. Na drugiej półce od góry stoją, oprawione $\mathrm{w}$ ramki, z imionami i nazwiskami oraz czasem trwania kadencji, fotografie sióstr prowincjalnych. Na trzeciej od góry różne drobne zgromadzeniowe pamiątki, medale , plakietki, itp. W szafie ściennej, na stronie wschodniej znajdują się muzealia (M). Wszystkie szafy przy drugim porządkowaniu archiwum zostały przejrzane. Nie skatalogowano szaf: na stronie południowej (przy oknie, zawiera głównie publikacje książkowe, maszynopisy), szafy naprzeciw niej ( maszynopisy z programami odnowy, kserówki z listów założycielki, odchodów stulecia zgromadzenia i inne) i pół szfy górnej (na odwrocie złączonych), gdzie znajdują się akta tzw. zespołu B.

Siostra archiwistka miała spotkanie z siostrami przełożonymi na temat wymogów odnośnie do pisania kronik i sprawozdań. Opracowane przez nią w formie pisemnej wskazówki zostały przekazane siostrom przełożonym, odpowiedzialnym za dostarczenie ich do archiwum. Inne spotkanie dotyczyło zbierania materiałów historycznych na temat domów, prac magisterskich sióstr i archiwum domowego. Do całkowitego spisania akt w archiwum nie doszło dlatego, że s. M. Teresa Górska została w roku 2003 powołana na stanowisko przełożonej lokalnej ${ }^{86}$; prace $w$ archiwum zeszły na plan dalszy ${ }^{87}$. Po ponownym powrocie do pracy w archiwum w 2006, po odbytych warsztatach archiwistycznych w Zakroczymiu w roku 2007 i wizycie w archiwum na KUL i w Ośrodku ABMK w Lublinie, archiwistka nabrała przekonania, że trzeba poddać rewizji to co dotąd zrobiła, pogłębić wiedzę z dziedziny archiwistyki, by wykonywać zawód archiwistki we właściwy sposób. Temu celowi ma służyć Podyplomowe Studium Archiwistyki na UMK w Toruniu i praca dyplomowa.

${ }^{86}$ s. M. T. Górska pełniła funkcję przełożonej lokalnej we wspólnocie Jezusa Mistrza z Nazaretu w Warszawie w czasie 21 VIII 2003 do 27 VIII 2006 i równocześnie archiwistki prowincjalnej.

${ }^{87}$ Prace w archiwum ograniczały się do tego co konieczne: zbierania $\mathrm{z}$ domów corocznych kronik i sprawozdań. 


\section{PORZADKOWANIE ZASOBU ARCHIWUM PROWINCJI NAJŚWIĘTSZEGO IMIENIA JEZUS W WARSZAWIE}

Przy tworzeniu schematu porządkowania w/w archiwum nie można posłużyć się układem pierwotnym, kancelaryjnym. $Z$ historii archiwum wynika, że nie było korelacji między kancelarią a archiwum, niemniej znalazły się w nim materiały przez nią wytwarzane. Struktura zasobu Archiwum Prowincji Najświętszego Imienia Jezus w Warszawie wynika z rodzaju posiadanych akt, która jest uzależniona od wewnętrznej organizacji zgromadzenia, jego zarządu oraz celu (misji) ${ }^{88}$, który wyznacza zadania apostolskie. Ważny jest rozwój zgromadzenia i zasięg terytorialny apostolatu, baza materialna, jego znaczenie w życiu Kościoła i społeczeństwa, a także praktyka i formy kancelaryjne ${ }^{89}$. „O strukturze zasobu archiwalnego danego zgromadzenia będzie decydowało pochodzenie archiwaliów z jednej czy wielu kancelarii, lub spoza kancelarii, rodzaj dokumentów i akt oraz ich ilość. (...) Zasób archiwalny, znajdujący się w archiwum żeńskiego zgromadzenia apostolskiego [do takiego należą siostry nazaretanki] może składać się z jednego lub wielu zespołów czy kolekcji i może być podzielony na wiele serii, podserii, punktów i podpunktów, w ramach których w sposób chronologiczny będą ułożone jednostki archiwalne. Struktura zespołu archiwalnego czyli układ rzeczowy powinien zasadniczo odpowiadać strukturze kancelarii, która go wytworzyła, a ponadto winien być jasny, przejrzysty i w pełni odpowiadający treści akt" ${ }^{\prime \prime 0}$. W przypadku omawianego zasobu będzie to zasób jednozespołowy. K. Trela twierdzi, że im większa jest ilość archiwaliów zróżnicowanych pochodzeniem i rodzajem akt, tym bogatsza będzie struktura danego zespołu archiwalnego, a także że w większości wypadków składają się one z zespołów otwartych, rzadziej zamkniętych. Mimo możliwych pewnych uogólnień, nie można stworzyć jednolitego wzorca struktury zasobu archiwalnego dla w/w zgromadzeń. Dlatego każdy zakon musi indywidualnie podjąć trud uporządkowania własnego zasobu. Autorka przytacza-

${ }^{88}$ Pojęcia misji i charyzmatów istnieją w Kościele od jego początków. W odniesieniu do życia konsekrowanego krystalizują się po Soborze Watykańskim II. (Od „Perfecte Caritatis” (28.10.1965) do Posynodalnej Adhoracji „Vita Consecrata” (25.03.1996). W Vita Consecrata określa się misję jako ,uobecnienie w świecie samego Chrystusa przez osobiste świadectwo. (...) Można zatem powiedzieć, że osoba konsekrowana <pełni misję> na mocy samej swojej konsekracji, której daje świadectwo w sposób zgodny z programem swojego Instytutu. Jest rzeczą oczywistą, że jeśli charyzmat założycielski przewiduje działalność duszpasterską, to świadectwo życia oraz dzieła apostolskie i dzieła służące postępowi człowieka są równie ważne: i jedno i drugie jest znakiem Chrystusa, konsekrowanego dla chwały Ojca, a zarazem posłanego na świat dla zbawienia braci i sióstr" (VC, 72). Misja jawi się więc jako pojęcie szersze od charyzmatu, który jest drogą i sposobem jej realizacji. Zarówno powołanie do świętości (bycie świadkiem) jak i posłanie, by przez dzieła świadczyć wobec innych o Bogu, są jedną i tą samą zbawczą misją Chrystusa wobec nas samych i innych. Kapituła generalna w roku 2006 poświęcona była zagadnieniu misji i jej definicji.

${ }^{89} \mathrm{~K}$. Trela, Struktura zasobu archiwów żeńskich zgromadzeń apostolskich, ABMK, 69 (1998) s. 62.

90 Tamże, s.62 
nego artykułu podaje podstawowe elementy struktury zasobów archiwalnych i wymienia rodzaje archiwaliów charakterystyczne dla żeńskich zgromadzeń apostolskich. Z poniższych wskazówek będzie można korzystać pośrednio, gdyż odnoszą się one do archiwum zarządu generalnego, dlatego należy dokonać ich przełożenia na poziom archiwum prowincjalnego. „W strukturze omawianego zespołu będzie można wyróżnić przynajmniej jeden zespół, tj. akta zarządu generalnego, w skład którego wejdą grupy (serie) archiwaliów dotyczące organizacji instytutu zakonnego, w tym jego podstaw prawnych oraz działalności zarządu generalnego, a więc jego kontaktu $\mathrm{z}$ władzami kościelnymi i świeckimi, z własnymi członkiniami oraz innymi instytutami zakonnymi. Znajdą tu również miejsce grupy archiwaliów dotyczące rozwoju personalnego i terytorialnego danego instytutu zakonnego oraz jego działalności apostolskiej, majątku i dziejów. Do grupy dotyczącej organizacji żeńskiego instytutu apostolskiego będą należały różnego rodzaju akta ustawodawcze, stanowiące jego podstawę prawną w formie ustaw, konstytucji, dyrektoriów, statutów czy zwyczajników, drukowane bądź pozostające w rękopisie czy hektografie.

Akta związane z działalnością zarządu generalnego będą stanowiły akta kapituł generalnych, księgi protokołów z zebrań zarządu generalnego, sprawozdania, dekrety, zarządzenia i korespondencja z członkiniami zgromadzenia, z władzą kościelna i świecką oraz innych instytutów zakonnych. Mogą się one dzielić na podserie, punkty i podpunkty.

$\mathrm{Z}$ dokumentacji personalnej, która stanowi odrębną grupę (serię), należy wymienić różnego rodzaju księgi: księgę główną - zawierającą spis wszystkich członkiń, księgę postulantek, nowicjuszek, juniorystek, księgę zmarłych sióstr oraz dokumentację ślubów, teczki personalne i inne.

W zakresie rozwoju terytorialnego można wymienić akta domów, podstawy prawne domów, różnego rodzaju wykazy ewidencyjne, sprawozdania i tym podobne. W grupie archiwaliów związanych z działalnością apostolską zgromadzenia znajdować się mogą różnego rodzaju poszyty zarządzeń, umów, sprawozdań i wykazów prowadzanych przez zgromadzenie zakładów.

Do grupy (serii) archiwaliów dotyczących majątku zgromadzenia może należeć dokumentacja nieruchomości, akta kupna i sprzedaży, darowizny, sprawy sądowe, sprawozdania rachunkowe i księgi rachunkowe, księgi posagów, akta ubezpieczenia, a także dokumentacja techniczna, nieruchomości i ruchomości.

Do archiwaliów związanych z dziejami żeńskiego instytutu zakonnego zalicza się różnego rodzaju materiały kronikarskie, takie jak: kroniki, diariusze, wspomnienie, księgi pamiątkowe, albumy fotograficzne, spuścizny członkiń i innych osób związanych ze zgromadzeniem oraz opracowania historyczne, a także materiały muzealno - kartograficzne. Układ rzeczowy zespołu archiwalnego, który jest zaledwie wypunktowaniem grup (serii) akt zarządu generalnego, może składać się z dziesięciu i więcej serii czyli grup. Jest on jedynie układem orientacyjnym i odpowiada na pytanie jakie typy akt mogą się znaleźć w zasobie archi- 
walnym żeńskiego instytutu apostolskiego" ${ }^{\text {91 }}$. Powyższe wskazówki będą pomocne przy proponowaniu schematu układu Akt Archiwum Prowincji Najświętszego Imienia Jezus w Warszawie, z uwzględnieniem specyfiki instytutu i zasobu. Struktura zasobu archiwalnego w/w archiwum, przy zastosowaniu zasady wolnej proweniencji, jest oparta na organizacji i funkcjonowaniu zarządu prowincjalnego, zgodna $\mathrm{z}$ rodzajem i treścią archiwaliów.

\section{PROPONOWANY SCHEMAT UKLADU AKT ARCHIWUM PROWINCJI NAJŚWIĘTSZEGO IMIENIA JEZUS W WARSZAWIE}

\section{ANPW ${ }^{92}$ Zespól otwarty}

Seria A. Podstawy prawne Zgromadzenia

Podseria I - Konstytucje (w ujęciu chronologicznym)

Podseria II - Zwyczajniki i Statuty (w ujęciu chronologicznym)

Podseria III - Dyrektoria prowincjalne (w ujęciu chronologicznym)

Podseria IV - Ceremoniały (w ujęciu chronologicznym)

Podseria V - Podręcznik nazaretańskiej formacji (w ujęciu chronologicznym)

Podseria VI - Modlitewniki (w ujęciu chronologicznym)

Podseria VII - Zgromadzeniowe książki adresowe na dany rok (wykaz placówek, domów i sióstr we wspólnotach i apostolatach).

Seria B. Władze generalne i działalność władz prowincjalnych

Podseria I - Dekrety Kapituł Generalnych (w ujęciu chronologicznym)

Podseria II - zarząd generalny

1. Korespondencja przełożonej generalnej z przełożoną prowincjalną

2. Okólniki przełożonej generalnej do sióstr

3. korespondencja z siostrami

4. sprawozdania powizytacyjne

Podseria III - Protokoły z kapituł prowincjalnych (w ujęciu chronologicznym)

Podseria IV - zarząd prowincjalny

1. sprawozdania na kapitułę

2. księgi protokołów z zebrań zarządu prowincjalnego

3. okólniki przełożonej prowincjalnej

4. protokoły z zebrań zarządu z przełożonymi lokalnymi

${ }^{91}$ K. Trela, Struktura zasobu archiwów żeńskich zgromadzeń apostolskich, ABMK, 69 (1998) s. 63 i inne.

${ }_{92}$ Akta Archiwum Nazaretanek Prowincji Warszawskiej = Akta Archiwum Prowincji Najświętszego Imienia Jezus Zgromadzenia Sióstr Najświętszej Rodziny z Nazaretu w Warszawie 
5. korespondencja przełożonej prowincjalnej z przełożoną generalną

6. korespondencja przełożonej prowincjalnej z siostrami

7. korespondencja przełożonej prowincjalnej z instytutami żeńskimi

8. korespondencja przełożonej prowincjalnej z instytutami męskimi

Seria C. Korespondencja z władzami kościelnymi

Podseria I - Stolica Apostolska

Podseria II - Prymas Polski

Podseria II - Biskupi

Podseria III - Kurie biskupie

Podseria IV - Ks. Proboszczowie

Podseria V - Kapłani diecezjalni

Seria D. Korespondencja z państwowymi i instytucjami świeckimi

Podseria I - Urząd do Spraw Wyznań / Ministerstwo Spraw Wewnętrznych

Podseria II - Wydział Finansowy / Ministerstwo Finansów

Podseria IV - Gmina / Kuratorium / Ministerstwo Oświaty

Podseria III - Urząa Rady Miejskiej / Powiatowej / Wojewódzkiej

Podseria V - Różne instytucje świeckie

Seria E. Personalia

Podseria I - Ewidencja

Podseria II - Aspirantki

Podseria III - Postulantki

Podseria IV - Nowicjuszki

Podseria V - Juniorystki

Podseria VI - Opinie i decyzje zarządu prowincjalnego (dopuszczanie do kolejnych etapów formacji)

Podseria VII - Formacja sióstr po ślubach wieczystych

Podseria VIII - Dokształcanie religijne sióstr

Podseria IX - Jubileusze sióstr

Podseria X - Siostry przebywające na eksklaustracji

Podseria XI - Siostry ślubów wieczystych, które opuściły Zgromadzenie

Podseria XII - Karty personalne sióstr zmarłych

Podseria XIII - Księga sióstr zmarłych

Podseria XIV - Wspomnienia pośmiertne o siostrach w języku polskim

Podseria XV - Wspomnienia pośmiertne o siostrach w języku angielskim

Podseria XVI - Księgi posagów sióstr

Podseria XVII -Testamenty, posagi, różne stare dokumenty

Podseria XVIII - Meldunki 
Podseria XIX - Emerytury

Podseria XX - Teczki personalne Sióstr

Podseria XXI - Teczki Przełożonych Generalnych, Delegatki Generalnej i Sióstr Prowincjalnych

Seria F. Życie duchowe

Podseria I - coroczny plan duszpasterski prowincji

Podseria II - formacja stała

Podseria III - formy duchowej odnowy ( dni skupienia i coroczne rekolekcje)

Podseria IV - odnowy

Podseria V - inne formy odnowy (rocznice, jubileusze, pielgrzymki)

Podseria VI - kształcenie religijne sióstr

Seria G. Domy prowincji i ich działalność

Podserie I (domy w ujęciu chronologicznym)

Seria H. Majątek / Finanse

Podseria I - Dokumentacja hipoteczna nieruchomości domów wg chronologii

Podseria II - Dokumenty kupna i sprzedaży

Podseria III - Ubezpieczenia

Podseria IV - Umowy

Podseria V- Wydział finansowy

Podseria VI - Sprawozdania finansowe na Kapitułę Generalną

Podseria VII - Roczne Sprawozdania finansowe prowincji wysyłane do Zarządu Generalnego

Podseria VIII - Roczne Sprawozdania finansowe z domów

Podseria IX - Pożyczki

Podseria X - Rachunki

Podseria XI - Remonty

Podseria XII - Księgi rachunkowe

Podseria XIII - Budowy / przebudowy domów (plany) i kosztorysy domów wg chronologii

Podseria XIV - Sprawy cła

Podseria V - Sprawy finansowe domów wg ich oznakowania

Seria I. Materiały i opracowania historyczne

Podseria I - Osoba Założycielki Zgromadzenia. Dokumenty rodzinne spuścizna piśmiennicza bł. Franciszki Siedliskiej

Podseria II - Opracowania historyczne o Zgromadzeniu. 
Podseria III - Błogosławione nazaretanki i sprawy beatyfikacji

Podseria IV - Prace dyplomowe i magisterskie osób spoza zgromadzenia o zgromadzeniu

Podseria VI - Kasety video o Zgromadzeniu

Podseria V - Zbiory muzealne

Seria J. Dorobek naukowy i artystyczny

Podseria I - Prace dyplomowe i magisterskie sióstr

Podseria IV - Taśmy magnetofonowe, CD z nagranimi sióstr

Podseria V - Fotografie i klisze

Podseria VI - Pieśni (z nutami i bez) o tematyce zgromadzeniowej

Akta domów zlikwidowanych (w układzie chronologicznym)

Podseria I - Lublin - Dom pod wezwaniem Ofiarowania Matki Bożej, ul. Niecała nr 21, (1919 - 9 X 1924)

Podseria II - Poznań, Dom św. Anny, ul. Szelaggowska 47/49 (28 VIII 1937 - XI 1939)

Podseria III - Wilno - Dom Eucharystycznego Serca Pana Jezusa, ul. Sierakowskiego 13, (1906-1945)

Podseria IV - Ostrzeszów, Dom św. Michała Archanioła, ul. Zamkowa (1936-1954)

Podseria V - Kuflew, Dom św. Józefa (27 IX 1978 - 1 VII 1982)

Podseria VI - Kamianna, Dom bł. O. Maksymiliana Kolbe (10 VIII 1982 - 31 V 1983).

Podseria VII - Boguszyce, Dom Maryi z Nazaretu (1 V 1967 - 30 VI 1983)

Podseria VIII - Tursko, Dom Najświętszej Rodziny (04 XI 1967 - 29 VIII 1985)

Podseria IX - Ligota, Dom św. Józefa (VII 1954 - X 1966)

Podseria X - Warszawa, Dom Matki Marii od Pana Jezusa Dobrego Pasterza (28 VIII 1987 - VI 2002), ul. Chłodna 9.

Podseria XI - Madryt, Dom Jezusa z Nazaretu (29 XII 1996 - 2003). Brak erekcji. Claudio Coello 94, 28006 Madrit, Hiszpania.

Podseria XII - Suwałki, Dom Św. Franciszka z Asyżu (7 XII 2001 - VI 2004). Ul. 11. Listopada 3/4, 16-400 Suwałki.

Podseria XIII - Szczuczyn, Dom Matki Bożej Fatimskiej (18 V 1995 - 15 VI 2005). Ul. Komsomolska 63/18, 231510 Szczuczyn, Białoruś.

Podseria XIV - Gniezno, Dom Miłości Świętej Rodziny (25 II 1994 - 31 VII 2007). Osiedle Orła Białego 20, 62-200 Gniezno.

Podseria XV - Czudnów. Filia domu w Żytomierzu. Istnieje od 2003 roku, zawieszony w roku 2005. Zlikwidowany 31 październik 2007. Ukraina. 
Podseria XVI - Nowojelnia. Istnieje od 2004 roku jako Filia Domu w Nowogródku. Zlikwidowany 15 X 2007. Białoruś.

Podseria XVII - Druskienniki, Dom Matki Bożej Ostrobramskiej (1995 - 2008), nie erygowany), Ul. Mizaru 3, 234690 Druskienniku, Zamknięty jako dom w 2003 roku, filia domu w Grodnie 1. Zamknięty w maju 2008, Litwa.

Zaproponowany schemat porządkowania (układu akt) Archiwum Prowincji NajświętszegoImienia Jezusw Warszawieuwzględniastrukturęzarządzaniaw zgromadzeniu (akta pochodzą z kancelarii prowincji, a także spoza niej). Na zasób tegoż archiwum wpływa charakter instytutu, który wynika ze struktury zarządzania, na który ma wpływ jego charyzmat i misja. Ten duchowy wymiar instytutu, który ukonkretnia się również w charakterze posiadanych akt w/w archiwum, wyróżnia go wśród innych apostolskich zgromadzeń dziewiętnastowiecznych. Jest to Archiwum Prowincji Najświętszego Imienia Jezus Zgromadzenia Sióstr Najświętszej Rodziny z Nazaretu. Każde zgromadzenie ma konstytucje, statuty, tyle tylko że są one różne, choć służą temu samemu celowi. Charyzmat i misja, które je „zabarwiają" swoistą dla danego zgromadzenia duchowością, można porównać do impresjonistycznych obrazów Claude Monet. Ten sam przedmiot, w innym oświetleniu, w zależności od pory dnia wydaje się inny, na przykład katedra w Rouen, czy pejzaże tegoż malarza. Z charyzmatu każdego instytutu pochodzi ów koloryt, który zabarwia duchowość danego zgromadzenia dominującą w danej epoce barwą. Powracając na grunt archiwum, jego zasobu, trzeba pamiętać, że nawet ten sam schemat układu akt wypełnia się inaczej ujętą treścią. To zróżnicowanie jest bogactwem danego zasobu, jego niepowtarzalną strukturą.

$\mathrm{Z}$ pewnością teoretyczny schemat układu akt $\mathrm{w} / \mathrm{w}$ archiwum $\mathrm{w}$ praktyce okaże się nie tak oczywisty i prosty. Między teorią a praktyką jest droga do przebycia, która niekiedy musi ulec zmianie. Trzeba być otwartym na niespodzianki, co nie oznacza, że nie należy planować i przewidywać. Temu właśnie służy zaproponowany schemat. Jest on punktem wyjścia do dalszych prac, by model w/w archiwum coraz bardziej odpowiadał wymaganiom, jakie stawia w tym przedmiocie współczesna wiedza archiwalna.

$* * * * *$

Bez wątpienia dzieje i charakter Zgromadzenia Sióstr Najświętszej Rodziny z Nazaretu mają wpływ na gromadzony zasób: jego ilość, rodzaj akt, zasięg terytorialny i stan zachowania. Charakterystyczną cechą omawianego zasobu, uksztaltowaną przez historię i charakter instytutu, jest jego organizacja (podstawy prawne), międzynarodowy charakter (różne źródła akt), struktura zarządzania (scentralizowana), taka sama dla całego instytutu, takie same etapy formacji członków, działalność (domy i placówki apostolskie), zmieniająca się wprawdzie w zależności od warunków historycznych danego kraju i wyzwań, jakie niesie każda epoka, ale od początku, poprzez charyzmat, ukierunkowana na rodzinę, głównie poprzez działalność edukacyjną dzieci i młodzieży (w Polsce różnego typu szkoły i przed- 
szkola). Z działalnością nierozerwalnie łączą się kontakty: z Kościołem, władzami państwowymi i świeckimi oraz sprawy majątkowe i finansowe. Można powiedzieć, że zarówno tworzona ciaggle historia zgromadzenia i różnego rodzaju twórczość jego członkiń, w tym także życie duchowe oraz publikacje, taśmy magnetofonowe czy nagrania na CD są dowodem jego żywotności i zarazem jej dokumentacją.

Jak ukazano na proponowanym schemacie układu Akt Archiwum Prowincji Najświętszego Imienia Jezus w Warszawie, na zasób archiwum składa się jeden zespół. Jest on otwarty, w jego skład wchodzi dziesięć serii, a te z kolei dzielą się na podserie. Akta domów zlikwidowanych tworzą odrębną grupę w układzie chronologicznym, który wydaje się praktyczny z tego względu, że mogą dochodzić do niej akta następnych domów, nie burząc istniejącego już układu. Niektóre z nich zlikwidowano w wyniku zmiany granic państwowych, inne nie odpowiadały charyzmatowi instytutu, powstawały w sytuacji, gdy zgromadzenie skazane było na przetrwanie i podejmowanie pracy niezgodnej z jego powołaniem. Inne były próbą działania $\mathrm{w}$ środowisku, które nie zawsze rozumiało właściwie cel i sens istnienia życia konsekrowanego i chciało działalność instytutu wykorzystywać do celów własnych, nie zawsze związanych z ewangelizacją. Były też pomyłki ze strony instytutu: brak odpowiedniego przygotowania członków, brak otwarcia na nowe wyzwania i nowy sposób apostołowania, czy wreszcie brak środków finansowych, który nie pozwolił na rozwój placówek. Stąd przemieszczanie się działalności apostolskiej zgromadzenia, zamykanie i powstawanie placówek, które obecnie są bardziej mobilne $\mathrm{z}$ tego też względu, że nie są własnością zgromadzenia.

Bez wattpienia sytuacja w Polsce, a szczególnie II wojna światowa i powojenne czasy komunistyczne, wycisnęła swoje szczególne niszczycielskie piętno zarówno na dziejach jak i na zasobie Archiwum Prowincji Najświętszego Imienia Jezus z siedzibą w Warszawie. Prowincja powstała w 1925 roku i wolnością cieszyła się zaledwie 14. lat. Nie do odtworzenia są straty, które nastąpiły w czasie wojny i po niej. Widoczne jest to w porównaniu z osiagnięciami innych prowincji zgromadzenia na Zachodzie.

Kolejne lata będą dopisywały dzieje prowincji. Sam zasób wymienionego archiwum wymaga nadal wielu poważnych prac: w pierwszym rzędzie czeka porządkowanie zespołu i sporządzenie inwentarza, opracowanie statutu archiwum, „zsynchronizowanie” kancelarii i archiwum, powiększenie lokalu. Obecna praca jest kolejnym krokiem w pracy nad Archiwum Prowincji Najświętszego Imienia Jezus w Warszawie.

\section{ANEKS}

Zaprezentowana powyżej praca powstała w 2008 roku. Od tego czasu - mamy październik 2009 - udało się zrealizować jeden z wymienionych w jej zakończeniu postulatów, a mianowicie powiększenie lokalu i jego wyposażenie (stworze- 
nie odpowiedniej bazy materialnej), co bez wątpienia ułatwi dalszą realizacje wyszczególnionych zadań. Archiwum otrzymało nie tylko większą przestrzeń, ale urządzono go według wymaganych aktualnie standardów. Składa się ono z dwóch pomieszczeń: pracowni i magazynu archiwalnego, który spełnia warunki dla bezpiecznego przechowywania akt (oświetlenie, wentylacja, temperatura, nawilgotnienie, przesuwane specjalne regały). Pracownia $z$ kolei otrzymała nowy sprzęt, potrzebny do pracy ( nie chodzi tylko o komputer, drukarkę, itp., ale o duży, wygodny stół, na którym można się rozłożyć swobodnie z aktami, przeglądać je i segregować). Nie jest możliwe zrobienie w archiwum wszystkiego, co się powinno wykonać, bez stworzenia odpowiedniej bazy. Dobitnie o tym świadczy opis pracy pierwszej archiwistki naszego instytutu. Zarówno świadomość osób pracujących w archiwum (kształcenie archiwistyczne) jak i zrozumienie władzy zakonnej odnośnie do ważności tej dziedziny w życiu zgromadzenia, pomagają, by archiwa zakonne coraz pełniej spełniały wymagania, jakie stawia nam współczesna archiwistyka. W Prowincji Najświętszego Imienia Jezus Zgromadzenia Sióstr Najświętszej Rodziny z Nazaretu sprawa potrzeb archiwum i możliwości zrealizowania ich dojrzewała przez osiem lat. Cóż to jest jednak wobec dziejów naszych instytutów. Niemniej, gdy spotkają się zrozumienie ze strony władzy zakonnej i świadomość wagi spraw przez archiwistkę, owocuje to wcześniej czy później dobrymi rezultatami.

Dla zachęty wszystkich, którzy - jak i ja - borykają się w tym zawodzie, przytoczę opinię powizytacyjną mojej przełożonej generalnej:

\section{Dear Sisters,}

These archives have been prepared beautifully and will serve the province well into the future. I congratulate the Provincial Administration under the leadership of Sister Maria Błaszczyk, Provincial, as well a Sister Teresa Górska, Archivist, for the planning and development of these archival rooms. May God bless you for your efforts to preserve the history and works of the Holy Name of Jesus Province for future generations. Congratulations!

Gratefully,

Sister Janice Fulmer

Superior General ${ }^{93}$

\footnotetext{
${ }^{93}$ Drogie Siostry,

Archiwum zostało przygotowane wspaniale i będzie w przyszłości z pożytkiem służyć prowincji. Gratuluję Zarządowi Prowincjalnemu pod przewodnictwem siostry Marii Błaszczyk, przełożonej prowincjalnej, jak również siostrze Teresie Górskiej, archiwistce, za zaplanowanie i urządzenie archiwalnych pomieszczeń.. Niech Bóg błogosławi Wam za Wasz wysiłek i troskę, by zachować historię i dorobek Prowincji Najświętszego Imienia Jezus dla przyszłych pokoleń. Gratulacje!
} 
Załącznik nr 2

\begin{tabular}{|c|c|c|}
\hline Dzial & Nr teczki & Tytul teczki \\
\hline A (charyzmat) & 1 & Matka Założycielka \\
\hline A & 2 & Siostry Męczenniczki \\
\hline A & 3 & Siostra Małgorzata \\
\hline B (korespondencja/ dokumenty) & 1 & Kapituła Generalna \\
\hline B & 2 & Kapituła Prowincjalna \\
\hline B & 3 & Okólniki Przełozonej Generalnej \\
\hline $\mathrm{B}$ & 4 & Okólniki Przełożonej Prowincjalnej \\
\hline $\mathrm{B}$ & 5 & Protokoły z Rad Prowincjalnych \\
\hline $\mathrm{B}$ & 6 & Protokoły Zebrań Przełożonych \\
\hline B & 7 & Zarządzenia Zarządu Generalnego i Prowincjalnego \\
\hline B & 8 & Watykan \\
\hline B & 9 & Prymas Polski \\
\hline $\mathrm{B}$ & 10 & Kuria Warszawska \\
\hline $\mathrm{B}$ & 11 & Inne Kurie Biskupie \\
\hline $\mathrm{B}$ & 12 & Kirche in Not, Renovabis \\
\hline $\mathrm{B}$ & 13 & Konferencja Wyższych Przełożonych \\
\hline B & 14 & Development Office CSFN \\
\hline $\mathrm{B}$ & 15 & Sekretariat Episkopatu \\
\hline B & 16 & Fundusz Kościelny \\
\hline B & 17 & Władze Państwowe \\
\hline B & 18 & Sprawy z innymi Zgromadzeniami \\
\hline $\mathrm{B}$ & 19 & Korespondencja z Generalatem \\
\hline B & 20 & Inne Prowincje \\
\hline B & 21 & Inne sprawy Zgromadzenia (NIP, Regon) \\
\hline $\mathrm{B}$ & 22 & Szkoły CSFN \\
\hline B & 23 & Przedszkola CSFN \\
\hline B & 24 & Duszpasterstwo Powołań \\
\hline $\mathrm{B}$ & 25 & Terminarz Prowincji \\
\hline $\mathrm{B}$ & 26 & Oferty nowych placówek \\
\hline $\mathrm{B}$ & 27 & Pomoc finansowa z zagranicy \\
\hline B & 28 & Misje \\
\hline B & 29 & Nuncjatura (w Polsce i na Białorusi) \\
\hline B & 30 & Archiwum \\
\hline B & 31 & Statystyka wewnątrz Zgromadzenia \\
\hline $\mathrm{B}$ & 32 & Studia Wyższe \\
\hline $\mathrm{B}$ & 33 & KUL \\
\hline B & 34 & UKSW \\
\hline $\mathrm{B}$ & 35 & Stowarzyszenie Najświętszej Rodziny \\
\hline $\mathrm{C}$ (formacja/ personalne) & 1 & Postulat \\
\hline $\mathrm{C}$ & 2 & Nowicjat \\
\hline $\mathrm{C}$ & 3 & Juniorat \\
\hline $\mathrm{C}$ & 4 & Formacja \\
\hline $\mathrm{C}$ & 5 & Odnowa \\
\hline $\mathrm{C}$ & 6 & Dokształcanie \\
\hline
\end{tabular}




\begin{tabular}{|c|c|c|}
\hline $\mathrm{C}$ & 7 & Jubileusze Sióstr \\
\hline $\mathrm{C}$ & 8 & Siostry Zmarłe \\
\hline $\mathrm{C}$ & 9 & Wspomnienia o Siostrach Zmarłych \\
\hline $\mathrm{C}$ & 10 & Jubileusze Zgromadzenia \\
\hline $\mathrm{C}$ & 11 & Opinia Mistrzyni \\
\hline $\mathrm{C}$ & 12 & Opinia Przełożonej/ Dyrektorki Junioratu \\
\hline $\mathrm{C}$ & 13 & Opinia Rady \\
\hline $\mathrm{C}$ & 14 & Skrutinium od 1997 \\
\hline $\mathrm{C}$ & 15 & Skrutinium przed 1975 \\
\hline $\mathrm{D}$ (domy) & 0 & Prowincja \\
\hline $\mathrm{D}$ & 1 & Warszawa - Dom Prowincjalny \\
\hline $\mathrm{D}$ & 2 & Kalisz 1 \\
\hline $\mathrm{D}$ & 3 & Ostrzeszów \\
\hline $\mathrm{D}$ & 4 & Łuków 1 \\
\hline $\mathrm{D}$ & 5 & Żdżary \\
\hline $\mathrm{D}$ & 6 & Łuków 2 \\
\hline $\mathrm{D}$ & 7 & Rawa Mazowiecka \\
\hline $\mathrm{D}$ & 8 & Ząbki \\
\hline $\mathrm{D}$ & 9 & Wytyczno \\
\hline $\mathrm{D}$ & 10 & Lublin \\
\hline $\mathrm{D}$ & 11 & Kolumna \\
\hline $\mathrm{D}$ & 12 & Bydgoszcz \\
\hline $\mathrm{D}$ & 13 & Zakopane 1 \\
\hline $\mathrm{D}$ & 14 & Oborniki \\
\hline $\mathrm{D}$ & 15 & Grodno 1, Białoruś \\
\hline $\mathrm{D}$ & 17 & Ciechocinek \\
\hline $\mathrm{D}$ & 18 & Jastrzębia Góra 1 \\
\hline $\mathrm{D}$ & 19 & Nowogródek, Białoruś \\
\hline $\mathrm{D}$ & 20 & Kaliningrad, Rosja \\
\hline $\mathrm{D}$ & 22 & Czerwonoarmijsk, Ukraina \\
\hline $\mathrm{D}$ & 23 & Lida, Białoruś \\
\hline $\mathrm{D}$ & 24 & Mińsk 1, Białoruś \\
\hline $\mathrm{D}$ & 25 & Konin \\
\hline $\mathrm{D}$ & 26 & Warszawa - szkoła \\
\hline $\mathrm{D}$ & 27 & Poznań \\
\hline $\mathrm{D}$ & 28 & Leszno \\
\hline $\mathrm{D}$ & 29 & Wasilków \\
\hline $\mathrm{D}$ & 30 & Zakopane 2 \\
\hline $\mathrm{D}$ & 31 & Włodawa \\
\hline $\mathrm{D}$ & 32 & Roszkowa Wola \\
\hline $\mathrm{D}$ & 33 & Kalisz 2 \\
\hline $\mathrm{D}$ & 34 & Iwieniec, Białoruś \\
\hline $\mathrm{D}$ & 35 & Mołodeczno, Białoruś \\
\hline $\mathrm{D}$ & 36 & Nowotroick, Rosja \\
\hline $\mathrm{D}$ & 37 & Grodno 2, Białoruś \\
\hline $\mathrm{D}$ & 39 & Budsław, Białoruś \\
\hline $\mathrm{D}$ & 40 & Żytomierz, Ukraina \\
\hline
\end{tabular}




\begin{tabular}{|l|l|l|}
\hline D & 41 & Warszawa - Ostrobramska \\
\hline D & 42 & Czudnów, Ukraina - nieerygowany-zawieszony w 2005 \\
\hline D & 43 & Kościeniewicze, Białoruś \\
\hline D & 44 & Mińsk 2, Białoruś \\
\hline D & 45 & Togliatti, Rosja \\
\hline D & 46 & Smorgoń, Białoruś - nieerygowany \\
\hline D & 47 & Ekibastuz, Kazachstan \\
\hline D & 48 & Karaganda, Kazachstan - nieerygowany \\
\hline D & 49 & Jastrzębia Góra 2 - nieerygowany \\
\hline
\end{tabular}

\title{
DAS ARCHIV DER PROVINZ DES ALLERHEILIGSTEN NAMENS JESUS - ORDEN DER SCHWESTERN DER ALLERHEILIGSTEN FAMILIE VON NAZARETH (CSFN / NAZARETHANERINNEN) IN WARSCHAU
}

\author{
Zusammenfassung
}

Die Geschichte und der Charakter des Ordens der Schwestern der Allerheiligsten Familie von Nazareth beeinflussen die gesammelten Materialien: ihre Menge, die Art der Akten, die territoriale Reichweite und den Erhaltungszustand. Zu den charakteristischen Merkmalen der hier besprochenen Bestände, die von der Geschichte und vom Charakter dieses Instituts geprägt wurden, gehört ihre Organisation (die Rechtsgrundlagen), ihr internationaler Charakter (unterschiedliche Aktenquellen), die (zentralisierte) Verwaltungsstruktur - dieselbe für das gesamte Institut, dieselben Etappen der Formation seiner Mitglieder und seine Tätigkeit (Häuser und apostolische Niederlassungen), die sich zwar in Abhängigkeit von den historischen Bedingungen und Herausforderungen der jeweiligen Epoche veränderte, aber von Anfang an - durch das besondere Charisma des Ordens - auf die Familie ausgerichtet war, hauptsächlich durch Bildungsarbeit mit Kindern und Jugendlichen (in Polen in unterschiedlichen Schultypen). Mit diesem Wirken untrennbar verbunden waren die Kontakte sowohl mit der Kirche als auch mit den staatlichen und weltlichen Behörden sowie Eigentums- und finanzielle Angelegenheiten.

Der Bestand des Archivs der Provinz des Allerheiligsten Namens Jesus in Warschau besteht aus einem Aktenensemble. Dieses ist offen, und zu ihr gehören zehn Serien, die sich wiederum in Unterserien gliedern. Die Akten der liquidierten Häuser bilden eine getrennte Gruppe in chronologischer Ordnung, die sich deshalb als praktisch erweist, weil die Akten der nächstfolgenden Häuser dazukommen können, ohne die schon bestehende Ordnung zu stören.

Zweifellos haben die Situation in Polen und besonders der 2. Weltkrieg und die kommunistische Nachkriegszeit sowohl die Geschichte als auch die Bestände des Archivs der Provinz des Allerheiligsten Namens Jesus mit Sitz in Warschau besonders destruktiv geprägt. Die Provinz war 1925 entstanden und konnte sich somit nur 14 Jahre lang ihrer Freiheit erfreuen. Ihre während des Krieges und in den Jahren danach erlittenen Verluste sind unwiederbringlich.

Der Bestand des Archivs erfordert weiterhin viele ernsthafte Arbeit. In erster Linie müssen das Aktenensemble geordnet und ein Inventarverzeichnis angefertigt, ein Statut des Archivs erarbeitet, die Kanzlei ,synchronisiert" und die Räumlichkeiten vergrößert werden. 


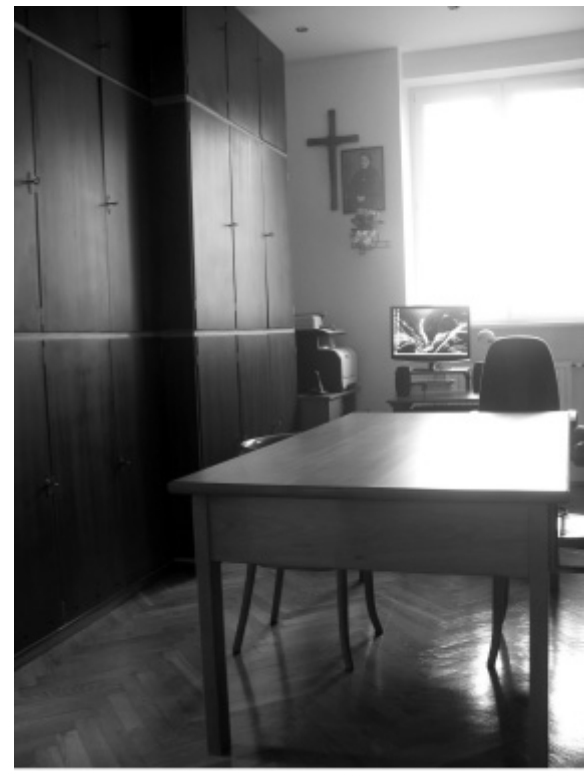

Pracownia Archiwum. Widok lewego skrzydła

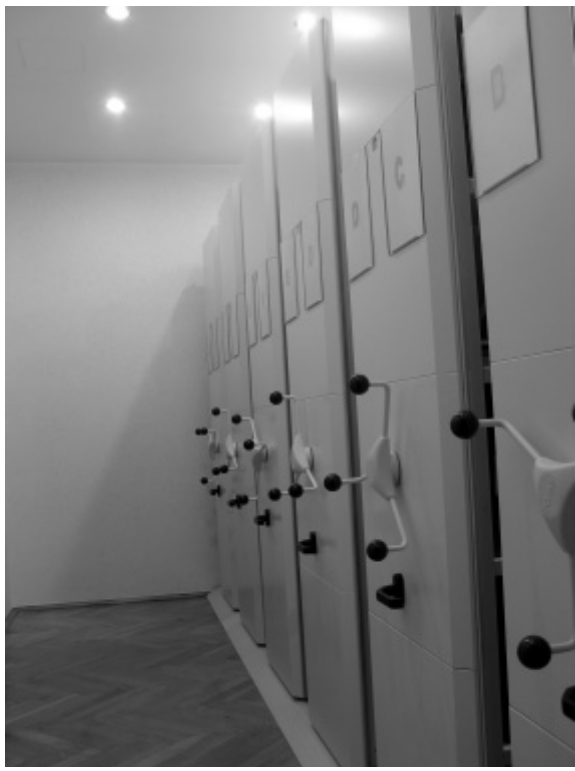

Regał w magazynie Archiwum

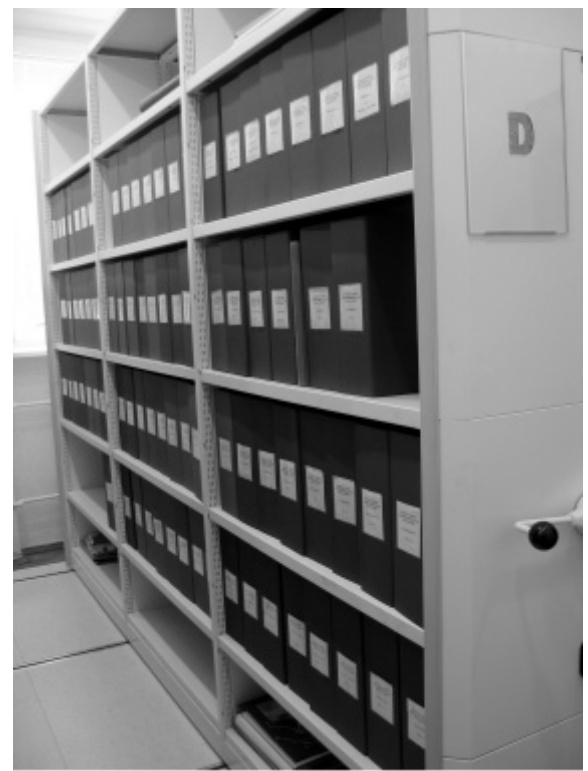

Otwarty regał w magazynie Archiwum 